\title{
Accountability in an Independent Regulatory Setting: The Use of Impact Assessment in the Regulation of Financial Reporting in the UK
}

\author{
Anna Samsonova-Taddei ${ }^{1} \cdot$ W. Stuart Turley ${ }^{1}$
}

Received: 20 July 2016/ Accepted: 28 March 2017/Published online: 7 April 2017

(c) The Author(s) 2017. This article is an open access publication

\begin{abstract}
The growing reliance on non-governmental independent regulators in many social and economic domains, including corporate financial reporting, has brought to the fore concerns over their regulatory accountability. This study looks at one aspect of the regulatory due process-regulatory impact assessment (IA). Drawing on the analytical framework developed by Bovens (Public accountability: a framework for the analysis and assessment of accountability arrangements in the public domain. CONNEX papers, Research Group 2, Democracy and Accountability in the EU, 2006, Eur Law J 13(4): $447-468,2007)$, we evaluate the contribution of IA as an instrument for enhancing regulatory accountability in the context of the Financial Reporting Council, an independent regulator for the accountancy profession in the UK. The study's findings suggest that, despite an increasing level of sophistication in the manner in which IA is used within FRC, the contribution of IA to regulatory accountability remains limited. Specifically, there are concerns as to whether IA is used to achieve a transparent and fair regulatory process or simply to maintain an image of good governance and justify policy decisions that would have been made even in the absence of IA.
\end{abstract}

Keywords Regulation - Accountability - Impact assessment $\cdot$ Due process $\cdot$ Financial reporting

Anna Samsonova-Taddei

Anna.Samsonova-Taddei@manchester.ac.uk

W. Stuart Turley

Stuart.Turley@manchester.ac.uk

1 Accounting and Finance Group, Manchester Business School, University of Manchester, Booth Street West, Manchester M15 6PB, UK

\section{Introduction}

Recent years have seen a sustained level of scholarly engagement with issues relating to accountability in a variety of settings, including government and the public sector (Mulgan 2003; Lægreid and Neby 2016), non-governmental organizations (Fassin 2009), the corporate sector (Reynolds and Yuthas 2008; Meng et al. 2013), and religious organizations (Yasmin et al. 2014). Examination of the nature and effectiveness of accountability arrangements in the regulatory context has been more limited (Jordana et al. 2015), but is of potential significance given major regulatory shifts characterized by the delegation of standard-setting and enforcement functions to independent regulatory agencies (IRAs) in a variety of socially significant regulatory domains (Mattli and Buhte 2005). In the case of corporate reporting, reactions to the incidence of cases of actual or alleged financial reporting malpractice have led to a questioning of the accountancy profession's self-regulatory remit and to changes to establish regulatory processes for developing reporting standards that are seen to be technologically competent yet independent (of the accountancy profession). In several different national environments, for example the USA, France and the UK, independent regulatory agencies have been established and have been entrusted with significant public remits and responsibilities (Osma et al. 2014; King and Case 2014). These agencies, however, are not subject to direct governmental control over their activities, which brings to the fore issues and questions relating to their regulatory accountability (Jordana et al. 2015), particularly at a time when, arguably, the need for regulation to restore public trust in the quality of corporate financial reporting and the integrity of accounting professionals has never been more pressing (Humphrey et al. 2013). 
Existing research has highlighted the importance of effective accountability mechanisms for the legitimacy of independent regulatory agencies themselves, the procedures through which they administer processes of policy development and the outcomes of those processes, and also the importance of regulators' actions being embedded in broader accountability arrangements established because "delegated decision-making has to respect certain procedural norms (transparency, notice-and-comment, reasongiving)" (Richardson and Eberlein 2011, p. 220). However, there has been limited investigation of the extent to which such procedural norms are operationalized by regulatory agencies and in the regulatory process. Related research has, however, provided insights into arrangements to demonstrate the "due process" in accounting and auditing standard setting (Baskerville and Newby 2002; Richardson 2008; Bamber and McMeeking 2016), the political consequences of the power dynamics underlying those arrangements (Kwok and Sharp 2005; Crawford et al. 2014), the nature of stakeholder participation and its influence on regulatory decision-making (Durocher et al. 2007; Hoffmann and Zulch 2014).

We make a contribution to this literature by analysing one aspect of the regulatory due process - the instrument of regulatory impact assessment (IA). Presented as part of an agenda for promoting better regulatory governance, IA has been designed, inter alia, with the purpose of enhancing the transparency of the process of policy development and increasing the "accountability of political decisions on the choice of regulatory measures and policies" (Kirkpatrick and Parker 2007, p. 2). IA was initially introduced in the USA, then other OECD member states (OECD 1995; Mandelkern Group on Better Regulation 2001) and a widening range of countries (Jacobs 2006; Radaelli 2004, 2005). IA is designed to assist policy development but also, importantly, to provide a "trail" of the due process undertaken in relation to regulatory decisions. The specific aim of this paper is to evaluate the contribution that IA makes to enhancing regulatory accountability of the Financial Reporting Council (FRC) the independent regulator for accounting and auditing in the United Kingdom (UK). Our interest in FRC is driven by the fact that the UK is a rare example of a country where independent regulatory agencies, alongside government departments, have long been subject to IA requirements and, also, because the British approach to IA has been considered in the 'avantgarde of impact assessment' (Renda 2006, p. 3). This provides an opportunity for a more comprehensive examination of the use of IA in an independent regulatory setting over a considerable period of time.

We provide rationalization of the specific accountability enhancing elements of IA and then review their application in 43 regulatory episodes relating to the development of accounting and auditing rules and standards initiated by FRC over the period between 2005 and 2015. We make use of the accountability framework suggested by Bovens $(2006,2007)$ to analyse FRC documents which demonstrate the application of IA in relation to each episode in order to assess whether the exercise of IA de facto contributes to greater accountability of FRC's regulatory decisions. The findings suggest that, despite an increasing level of sophistication in the manner in which IA is used within FRC, its contribution to regulatory accountability remains rather limited. Specifically, there are questions regarding the extent to which IA is used to achieve a transparent and fair regulatory process or simply to justify and validate the policy decisions that would have been made even in the absence of IA.

The remainder of the paper is structured as follows. The next section problematizes issues relating to regulatory accountability and the role of IA as applied to an independent regulatory setting. This is followed by a section that outlines the analytical approach employed to assess the efficacy of IA as an accountability tool and the evidence base for the study. The analysis of the evidence collected about the use of IA in connection with FRC regulation of accounting and auditing is presented in the next section, before the final section which draws conclusions.

\section{Regulatory Accountability, Impact Assessment and FRC}

This section introduces key concepts that are relevant to this study. Specifically, it problematizes the notion of accountability in a regulatory setting and the capacity of IA as a tool to enhance regulatory accountability. It also contains a discussion of the roles that IA can play in the context of independent regulation and provides a brief overview of the approach to IA adopted by FRC.

\section{Regulatory Accountability and IA}

In a broad sense, accountability has been defined as a "relationship between an actor and a forum, in which the actor has an obligation to explain and to justify his or her conduct, the forum can pose questions and pass judgements, and the actor may face consequences" (Bovens 2007 , p. 450). Over time the meaning of accountability has evolved beyond the emphasis on being called to account for one's actions, with accountability instruments now involving not just tools to report to the upper-level principals (for example, for approval of annual reports or 
multiple-control arrangements) but also to a wider variety of stakeholders and the public at large (for example, through releasing minutes of board meetings, agency resolutions and open consultations) (Fernandez-i-Marin et al. 2015)). In this sense, accountability has been described as a problem "of many eyes", involving complex considerations and related to a variety of fora that a given actor can be held accountable to (Lægreid and Neby 2016, p. 61).

Bovens (2007) argues that accountability is often equated with "good governance" which is "of high quality, at a low cost and [...] performed in a courteous manner" (p. 450). Consequently, in a regulatory setting, poor accountability has been linked to shortfalls in regulatory performance and heightened risk of regulatory capture (May 2007). However, attempts to conceptualize accountability in such a setting have been relatively scarce. Among the notable exceptions is the recent volume edited by Jordana and colleagues (2015) which provides a comprehensive perspective on regulatory accountability. The authors adapt Bovens's (2007) definition of accountability to a regulatory context as one that describes "a relationship between power-holders and those affected by their actions" (p. 3) and comprises two key components: answerability ("making power-holders explain and justify their actions") and enforceability ("allowing the participants in the forum to judge [poor performance]") (Jordana et al. 2015, p. 3). One means through which good accountability may be achieved is through the introduction of the formal procedures that specify a range of steps to be taken to ensure that the civil society can hold political elites and the regulatory institutions through which they operate answerable for their actions (Mulgan 2003; May 2007). Below, we refer to the existing literature on regulatory accountability and IA to argue that, as a tool of ex ante policy appraisal (Jacobs 2006; Radaelli 2010), IA represents an instrument to establish and maintain an effective accountability relationship between the regulator and forum members.

IA has been defined as a "process of problem definition, consultation, definition of alternative feasible options, economic analysis of the options, and a final choice that meets some criteria established ex ante, such as 'the benefits justify the costs' or 'maximization of social welfare' or, in simpler versions, 'minimization of compliance costs", (Coletti and Radaelli 2013, p. 1058). Hence, IA involves evaluation of various stages of regulatory development, from identifying policy alternatives and undertaking a comparative assessment of them to selecting the preferred option (Kirkpatrick and Parker 2007). Therefore, one of the contributions of IA is its potential to describe a process of rulemaking (Coletti and Radaelli 2013) and make more observable, accessible and assessable the regulator's internal decision-making, which is normally hidden from the public eye. Having access to this information can thus enable a variety of stakeholders, from the political principal to policy recipients and the public at large, to make judgements as to the nature of the policy-making process and whether the policy outputs produced as a result of it are appropriate, credible and just (Radaelli 2010). Furthermore, IA relates to policy development which precedes regulatory action and can therefore be used as a dynamic tool for enhancing the dialogue between the regulator and its audiences (Radaelli 2010). This is in contrast to other policy appraisal tools that focus on ex post oversight, such as a Standard Cost Model (Coletti and Radaelli 2013).

The argument that we develop in this study is that IA has accountability-related properties that can enhance both the answerability of the regulator for its actions and enforceability that compels the regulator to justify these actions to its forum members (Jordana et al. 2015). The literature on IA (Radaelli 2010; Dunlop et al. 2012) provides support for this argument by reference to a range of aspects which highlight the potential role of IA as an accountability instrument. Firstly, prior studies of IA indicate that, in the context of delegated policy making, the instrument can promote greater and more dynamic forms of political control over the regulator's decisions by the political principal, such as government, an upper-level executive or affiliated regulatory authority. Radaelli (2010) explains how IA may play an important role in "inserting some principles (e.g. the benefits must exceed the cost) and hurdles (e.g. "no new rules unless a market failure is fully documented")" (Radaelli 2010, p. 92) to re-assure the political master that the broad political objectives are being served and to minimize the risk of deviation from those. IA may also contribute to the dynamism of the accountability relationship between the regulator and forum members through facilitating early-warning systems to detect politically dangerous or incongruent policy initiatives and allowing intervention before the final regulatory outputs are decided and endorsed (Radaelli 2010).

Secondly, IA can also contribute to downward accountability by improving a regulator's answerability to the recipients of regulation and the general public through stakeholder participation (Jordana et al. 2015). IA guidance in many countries, including the UK, requires that an IA report be published as part of the formal public consultation process. Dunlop et al. (2012), for example, point to the communicative element of modern IA as particularly important, with open consultation and "notice-and-comment" arrangements facilitating "dialogic" encounters between regulators and stakeholders (p. 27). In this regard, IA has a capacity to promote a "pluralist logic" of accountability, where the public consultation attends to the information demands of the political principal but also of a wider range of stakeholders, such as businesses, social 
groups, judiciary institutions and others. That said, it is important to recognize the possibility of variation across regulatory contexts in terms of the types of actors and networks that IA mobilizes. Radaelli (2004), for example, points to the risks of over-emphasizing certain policy constituents, such as members of the business community, over others, such as the general public. That approach can create imbalances in the representational mechanisms of policy making and also undermine the procedural legitimacy of regulation by reinforcing the perception that regulators use IA to project a certain 'desired' image.

Lastly, IA can improve enforceability (Jordana et al. 2015) by not only facilitating substantive understanding "of the cause and effect mechanisms that underpin the policy issue" (Dunlop et al. 2012, p. 27) but also compelling regulators to justify that regulatory solutions were produced on the basis of that kind of understanding, particularly through an emphasis on explanation, reason-giving, and the general rationality of a legislative process (Froud et al. 1998; Radaelli 2010). Indeed, one of the key objectives of IA is to facilitate technically superior regulatory solutions, based on robust evidence, to support the assessment of policy alternatives and selection of a preferred option (Jacobs 2006; Kirkpatrick and Parker 2007; Radaelli 2010). From a technocratic point of view, procedures such as cost assessment that now form part of IA provide means to streamline and make uniform regulatory decision-making to the extent that the process "becomes a more technical and less intuitive operation, with the burden of proof firmly assigned to those who propose or promote the regulation" (Froud and Ogus 1996, p. 222). Radaelli 2010 and Froud and Ogus (1996) link the monetized assessment of policies that IA encourages with the ideas of rational policy analysis which mimic the decision-making culture in the private sector by placing an emphasis upon "the careful definition of goals, the exploration of alternative means of achieving these, including a rigorous analysis of the costs and benefits of each option" (Froud and Ogus 1996, p. 222). Froud and Ogus (1996) also recognize, however, that the implementation of "numberbased" procedural steps is far from unproblematic as it is often the case that "knowledge of the consequences of each [policy] alternative is incomplete and the ability to appraise all possibilities systematically is limited" (p. 222).

\section{The Role of IA in the Context of IRAs}

The transfer of major policy-making remits to non-governmental regulatory agencies has brought to the fore some "fundamental issues concerning regulatory accountability" and related questions about "how accountability is achieved when non-governmental actors assume important roles in regulatory regimes" (May 2007, p. 9). Such concerns arise, to a significant degree, as a consequence of some of the characteristic features of the agencies themselves. Firstly, these agencies represent non-elected (through some form of a democratic process) institutions and, as a result, are vulnerable to a potential democratic legitimacy deficit. More specifically, independent regulators do not have the same degree of external credibility as state institutions because, as Maggetti (2010) argues, a transfer of policy-making authority from the state to independent regulators does not automatically lead to a similar transfer of legitimacy and, in fact, leads to what he calls a "net loss of legitimacy". This legitimacy shortage engenders a heightened awareness of the need for regulating agencies to maintain a public perception of themselves as producers of fair and representative policy outputs. Secondly, independent regulators usually enjoy greater operational autonomy compared to government departments as they function outside the ministerial hierarchy. Growing public concerns over the relative political isolation that independent regulators enjoy coupled with their virtual autonomy in decision-making motivate them to seek ways to demonstrate that "they are more proficient in producing qualitatively better policy outputs than democratic institutions" and that "they operate more lawfully, transparently, openly, and fairly than ordinary bureaucracies can do" (Jordana et al. 2015, p. 3). Thirdly, IRAs find themselves exposed to accountability claims that are more pluralistic in nature in the sense that the maintenance of upward accountability (to the affiliated upperlevel executive) is still a significant consideration but is supplemented by the greater perceived importance of downward accountability (e.g. to policy recipients). As Righettini and Grimaldi (2015, p. 145) argue, the rise of IRAs and the accompanying move from input-based to output-based democratic legitimacy has led to a fundamental shift in a "policy constituency" towards the recipients of regulation and other stakeholders affected by it.

The above constraints and considerations have had significant implications not only for the way in which IRAs organize the policy-making processes but also the accountability arrangements in relation to those processes and their outcomes. Specifically, prior studies have shown that IRAs often opt for accountability solutions that facilitate technocratic policy making (based on skills and performance assessment) and are helpful in effectively managing the relationship between the regulator and its wide-ranging audiences (Schrefler 2010, 2013; Righettini and Grimaldi 2015). Righettini and Grimaldi (2015, p. 148), for example, argue that IRAs often pursue accountability arrangements that rely on co-regulatory policy tools that "create mutual adjustments and compliance obligations" and are designed to address stakeholder demands for both information and justification. 
Importantly, they also point out that IA represents one such accountability tool. Indeed, one of the key accountabilityrelated properties of IA which is particularly relevant for IRAs (as discussed in the previous section) has to do with its ability to maintain perceptions of a knowledge-intensive regulatory process which is informed by a substantive understanding of the policy issues at hand and, importantly, to help regulators justify any resulting policy solutions by feeding into such perceptions (Froud et al. 1998; Radaelli 2010; Dunlop et al. 2012). In this regard, Schrefler's (2010) nuanced account of the underlying rationales behind the use of knowledge in the context of IRAs provides a useful reference point for our understanding of how exactly IA may help create and maintain the image that knowledgeintensity is an inherent property of independent policy making. Firstly, IA may help facilitate instrumental use of knowledge by IRAs by establishing a connection between research and policy decisions which ensures that "once policy problems are identified, knowledge is the means by which to select the best solution" (Schrefler 2010, p. 14) (for a similar view, see also Dunlop et al. 2012). In this regard, IA can help IRAs achieve their short-term objective to be seen as producing qualitatively better policy outputs as well as the long-term objective of increasing a general understanding of the issues at hand.

Secondly, the objective served by IA may also involve the strategic use of knowledge by IRAs, which may be both political and substantiating. More specifically, in the context of IRAs, the aforementioned properties of IA as a mechanism of political control may be mobilized by an independent agency as a means for "expanding its powers and resources and safeguarding its action from the potential opposition" of the oversight body or adjacent government department (Schrefler 2010, p. 14). The substantiating strategic usage of IA, on the other hand, may have more to do with the desire to "justify and support the predetermined/preferred policy solution" (Schrefler 2010, p. 10). In this case, IA is used effectively in an ex post fashion, that is, not as a tool for incorporating knowledge into the process of policy analysis and selection but as a means to support the pre-selected option and justify the subsequent policy decision to the accountability forum and weaken any possible challenges of that decision. Finally, organizations such as IRAs may use knowledge symbolically to gain legitimacy in the eyes of significant stakeholders or other policy actors and also to conform to the logic of appropriateness that encourages them to make an appropriate response to external pressures and expectations (Schrefler 2010). While, as we discussed earlier, IA can be used to project the image of rational policy making (Radaelli 2010), prior studies have also demonstrated that the ideas behind IA and the actual application of those are often decoupled, pointing to the widespread occurrence of what
Dunlop et al. (2012) termed the 'perfunctory' use of the instrument. In this vein, Schrefler (2010) further argues that the reliance on knowledge instruments (such as IA) can have a protective function in certain policy sectors (for example, regulation of professional services) where there is strong isomorphic pressure on regulators to be seen to make reference to expertise and research findings. It is also plausible that the perfunctory use of IA is more common in the earlier stages of IA adoption as, according to Schrefler (2010), the symbolic use of knowledge is often a preliminary form of the other two types of knowledge uses.

The above rationales behind the use of IA in the context of IRAs are not mutually exclusive and may evolve and coexist simultaneously. Before analysing how these rationales may shape the use of IA within FRC, we first present a brief overview of FRC and its formal approach to IA.

\section{IA in the Context of FRC}

The FRC was first established in 1990 as part of a major reform of the process for setting and overseeing compliance with accounting standards. In 2004, its role was changed significantly as a result of government reviews following the major corporate scandals of the early twenty first century (Turley 2008), and the responsibilities of the FRC were expanded to incorporate auditing as well as accounting rule making. The agency is an independent regulator separate from the accounting profession in the $\mathrm{UK}$, and its responsibilities include some statutory or quasi statutory roles that are devolved by government. Up to July 2012, FRC activities were reflected in several operating boards which had authority for either issuing standards or monitoring compliance. Specifically, the Accounting Standards Board (ASB) issued accounting standards as prescribed by the Companies Act 2006 (section 464) while the Auditing Practices Board (APB) exercised delegated authority to set practice and ethical standards for auditing to meet the Act's provisions requiring "appropriate independent arrangements" for regulation of auditing (section 1228 and Schedule 10, paragraphs 9, 10 and 22). A major reform of the structure was introduced from July 2012 and the names and responsibilities of the component parts of FRC were changed but the principal aspects of the approach to policy development remain the same. Currently, accounting and auditing standards, respectively, are considered and developed by the Corporate Reporting Council and the Audit and Assurance Council, as the constituent parts of FRC that have succeeded the ASB and APB. The standards are issued in the name of FRC itself rather than those of the separate units.

As an independent regulatory agency operating at arm's length from government but exercising significant statutory responsibilities, FRC has been subject to a government requirement to undertake IA. Over the years, the nature of this requirement has been subject to change. Specifically, in 
1998, the UK government introduced The Regulatory Appraisal Guide, a document considered to be the first formal guidance on IA (Cabinet Office 1998). Inter alia, this encouraged more detailed analysis of policy alternatives, including the so-called zero-option (leaving the existing regulation unchanged). Due to various initiatives and changes in government, the IA guidance has been subject to many revisions since it was first issued. A revised version of the guidance published two years later (Cabinet Office 2000) made it a formal requirement that IA reports accompany regulations produced by "all government departments and agencies where they exercise statutory powers and make rules with a general effect on others" (p. 5), which therefore applied to FRC. In subsequent years, the government's Legislative and Regulatory Reform Act in 2006, published following the Hampton review (HMSO 2005), introduced some further changes by, inter alia, requiring that the activities of the regulators (irrespective of whether they were government or independent) comply with the principles of good regulation in that they '(a) should be carried out in a way which is transparent, accountable, proportionate and consistent and (b) should be targeted only at cases in which action is needed' (Art. 19). The latest version of the guidance was published in 2015 (BIS 2015) and reaffirms the role of IA as a continuous process of policy appraisal. It requires that IA accompany any proposal-from either a domestic or international source, mandatory or voluntary, produced by a government department or a self-regulating institution-that may have an impact on public, private or civil society organizations.

In addition, a formal commitment to IA has been reflected in the FRC's own policy statements. Following the reform of 2004, the then newly reorganized FRC published its first Regulatory Strategy document (FRC 2004) stating commitment to "making effective use of Regulatory Impact Assessment" (p. 3), and this has been updated a number of times in subsequent years. The latest version of the document (FRC 2014) reinforces FRC's desire to be a regulator "driven by evidence, fairness and proportionality in deciding what action to take" and "to report openly on these activities and the reasons for them" (pp. 3-4). Importantly, it also restates the agency's commitment to the conduct of IA as a means to ensure the observance of the principles of transparency, accountability, proportionality, consistency and targeted action. ${ }^{1}$ The

\footnotetext{
1 The FRC's experience of IA had a significant influence on the development of the Position Paper on "Considering the Effects of Accounting Standards" which was published by the European Financial Reporting Advisory Group (EFRAG) in June 2012. The main elements of approach in that paper have been supported by a wide range of standard setters in the area of financial reporting across the European Union. Analysis of the explicit use of IA within the FRC's regulatory activities is therefore of relevance to understanding the potential contribution IA can make to the broader field of financial reporting regulation internationally.
}

FRC's current approach to IA is explained on its website where the agency states that it follows the latest government guidance on IA (BIS 2015) and also mentions three guiding principles it adheres to in producing impact assessments, namely:

- The work that goes into the production of an impact assessment should be proportionate to the importance of the proposal that it covers.

- Where a standard is being introduced as a direct response to legislation or regulation, or as part of an agreed policy commitment to adopt international standards of accounting or auditing, the impact assessment should explain the rationale for introducing the standard and should focus on any aspects of the proposed standard which augment the relevant legislation or augment or diverge from the relevant international standard.

where appropriate, we are particularly alert to the impact of proposals on small businesses. ${ }^{2}$

FRC activities in general and, in particular, the conduct of IA, are also subject to external oversight arrangements. In particular, FRC's policy-making practices are scrutinized periodically by the Better Regulation Executive (BRE), a directorate established as a result of the Hampton review within the government's Department for Business, Innovation and Skills (BIS) to lead the better regulation agendas. Interestingly, in 2010, BRE published results of a Hampton implementation review of FRC practices (BIS 2010), describing FRC's governance practices as demonstrating "a positive approach to better regulation" (p. 3). Specifically, the procedures for public consultation were found to be particularly strong, but the reviewers warned of the dangers of "consultation overload" and suggested FRC should set clearer priorities on the volume and content of consultation (p. 12). The review also found that the FRC needed to develop a more comprehensive approach to the analysis of the costs and benefits of its proposals, and to monitor better the accuracy of forecasted estimates. In addition, as a regulator with a significant public interest remit, FRC falls within the broader democratic accountability process and may, in principle, be held to account by institutions such as the UK parliament, which has been aptly described as having 'an appetite for scrutiny of regulatory reform' (Radaelli 2010, p. 99). For example, a report by the House of Lords' Select Committee (House of Lords 2007) stated that regulators "should commit to evaluating the impact of their work and monitoring the

\footnotetext{
$\overline{2}$ See https://www.frc.org.uk/About-the-FRC/Procedures/FRC-opera tional-policies/Impact-assessment.aspx (accessed 28th November 2016).
} 
extent to which they are providing value for money" (p. 36).

\section{Evidence Base and Analytical Approach to Assessing IA as an Accountability Tool}

\section{Evidence Base}

We have reviewed the use of IA in all regulatory episodes in the fields of accounting and auditing completed by FRC over a ten-year period between January 2005 and December 2015 (see Appendix for a full list). We therefore focus on the time following the widening of the FRC's responsibilities which led to the emergence of FRC as we know it now, as the UK's independent regulator for both accounting and auditing. By a 'regulatory episode' we identify any consideration of policy-making or regulatory activity leading to the issuance of new or revised regulations for financial reporting or auditing. The total number of regulatory episodes reviewed is 43 , including projects on the development and revision of auditing and accounting standards, and ethical standards for auditors. In each case, the publication of consultation papers, discussion papers, exposure drafts and standards are all taken as part of a single regulatory episode but each new consideration of a possible revision to existing standards is taken to constitute a new episode. One of the authors served as a member of one of the FRC's Boards. As a result, we were able to construct a comprehensive database of documentary materials which serves as the main source of evidence for our analysis. Additionally, we also benefitted from the interviews with four individuals that held general responsibilities within FRC for the conduct and oversight of IA. The interviews represent secondary data source and were used mainly as a means to gain a general understanding of the organization of the IA process within FRC.

\section{An Analytical Approach}

Our analytical framework for assessing the efficacy of IA as an accountability tool is presented in Fig. 1 and is based on the work of Bovens $(2006,2007)$ which address accountability as an object of inquiry. Specifically, in Bovens's view, assessment of any accountability mechanism should comprise two considerations, namely: (1) an evaluation of the procedures through which this type of mechanism is enacted and (2) a systemic evaluation of the overall purpose that it serves as well as its overall appropriateness. For the purpose of this study, the following paragraphs will discuss how these two levels provide key dimensions for our assessment of the efficacy of IA as an accountability tool.
The procedural assessment, according to Bovens (2007, p. 467), involves questions about the manner in which the accountability mechanism supports the functionality of what he termed "accountability phases", comprising: (1) an information phase (proper provision of information about an actor's conduct); (2) a debating phase (proper discussion and debate); and (3) a judgement phase (a possibility for a proper judgement by the accountability forum about the nature of policy making and its outcomes). Bovens's conceptualization of the accountability process closely relates to that developed by Jordana et al. (2015, p. 7) who mention answerability and enforceability as two key characteristics of accountability, where the former is "based on information [and] dialogue" between the regulator and the forum and the latter means judgements about the regulator's conduct.

IA literature shows that an evaluation of the procedural quality of IA practices most commonly involves an assessment of compliance with IA guidelines (Vibert 2004; Renda 2006; Cecot et al. 2008; Dunlop et al. 2012). One of the common methods of assessment used in these studies has been a scorecard approach where a score is awarded when a specific quality criterion is met, such as the inclusion of estimated costs/benefits. While this form of approach enables a generalized, measured assessment of the use of IA and its overall quality, it often struggles to provide a more nuanced understanding of the application of particular IA procedures. In this study, we refer to the provisions of UK government guidance on IA as a standard of IA best practice with a particular focus on the provisions relating to the procedures that facilitate the three accountability phases (Bovens 2007). Rather than relying solely on scorecards, we first relate adherence to the provisions of IA guidance with the accountability enhancing elements of IA (see below); this is then followed (in "Analysis" section) by an assessment of the FRC regulatory episodes to demonstrate the degree to which those elements are executed and associated challenges (see Fraas and Lutter 2011, for a similar approach).

As mentioned earlier in the paper, the UK government guidance on IA that serves as a benchmark for our analysis has been subject to a number of revisions since its first publication in 1998 (Cabinet Office 1998, 2000, 2003; BIS 2011, 2015). While the content of those revisions has varied, applying increasingly more detailed and prescriptive recommendations, the general idea of what IA means has not changed significantly. Specifically, the general requirement has been that IA should involve a range of steps, including: (1) identifying the policy problem, (2) identifying desired policy objectives, (3) identifying viable policy options that will achieve those objectives, (4) identifying the impact of each of those options (both negative and positive), (5) valuing the costs and benefits 
Two-tier assessment

of IA as an

accountability tool

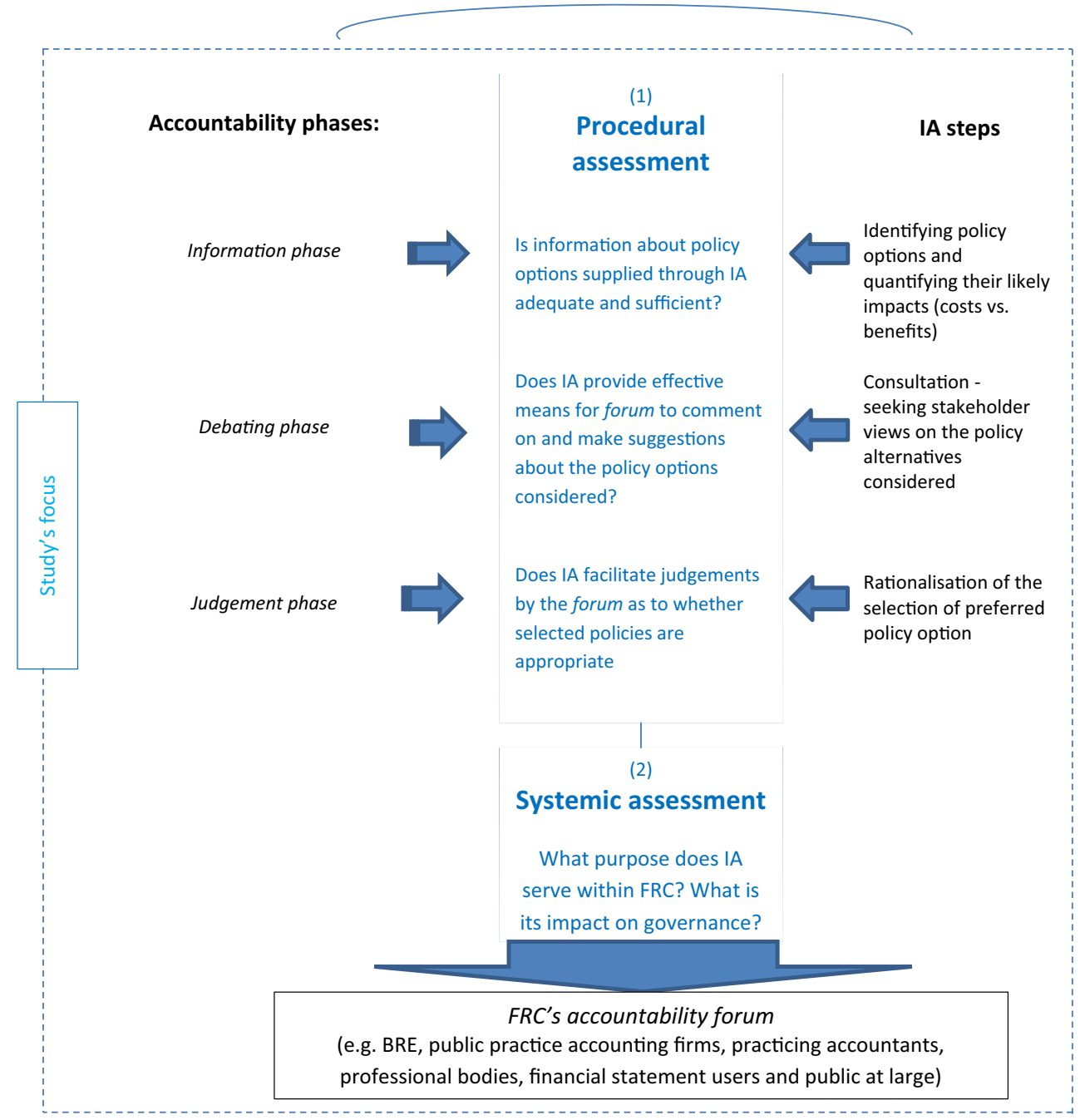

Fig. 1 Efficacy of IA as a tool for enhancing regulatory accountability: An analytical framework

related to each option and selecting the preferred option, and (6) evaluating implemented policy. Further, since 2003, the guidance has also required that regulators administer an open consultation which may occur at different points in the policy cycle (Cabinet Office 2003). Steps 1 and 2, to a large extent, are determined by the incidence of an accounting or auditing issue and by the general objectives of FRC, and so are of less importance to us. Step 6 is also outside the study's scope because our analysis is concerned with the use of IA up to the point at which a regulatory outcome has been determined.

Thus, the primary focus of our assessment are steps 3, 4 and 5 as well as the public consultation element of IA, as these provisions relate most closely to the accountabilityenhancing properties of IA discussed earlier. Specifically, steps 3 and 4 relate to the capacity of IA to facilitate the information phase of accountability (Bovens 2006, 2007) by providing the forum with relevant information about the policy options at hand, including the cost burden that each option imposes as against the quantified benefits of implementation and compliance. Further, the consultation requirement contained in IA guidance highlights the potential for IA to facilitate the debating phase of accountability by enabling a discussion and dialogue between the regulator and the forum to collect stakeholder views on the key assumptions, estimates and evidence used in policy making. And lastly, Step 5 may be seen as supporting the judgement phase of accountability as it demands that the regulator justifies the selection of a preferred option by demonstrating a documented assessment 
of whether the benefits associated with it outweigh the cost of implementation, so that the forum members are able to form judgements about the appropriateness of the regulator's decision.

Our analysis has assessed all identified episodes in terms of evidence of compliance with the steps of IA described above (steps 3, 4, 5 and the public consolation requirement). As a result, we have identified three groups of episodes, namely: (1) episodes with no elements present: (2) episodes addressing some but not all elements, and (3) episodes where all elements were present. Furthermore, in addition to this generic classification of all episodes, we also provide a more detailed narrative-style discussion of illustrative episodes to exemplify the extent to which relevant elements of IA have been applied and supporting procedures followed in practice.

The second part of an accountability assessment, according to Bovens $(2006$, 2007), should consider the systemic effects and general purposes of a given accountability instrument. Applied to our case, such a systemic assessment involves questions about IA itself and the actual purpose it serves within FRC in light of the FRC's publicly declared commitment to transparency and accountability. More specifically, Bovens (2007) suggests that such questions should focus on the functional aspects of the accountability arrangement and whether it yields relevant information about the regulator's conduct. A key issue in this regard is whether IA provides policy stakeholders constituting the FRC's accountability forum with a good understanding of the processes of rule formulation, and more importantly, yields opportunities to influence the regulator's conduct and the direction of regulatory policy. Another set of questions, according to Bovens (2006, 2007), should seek to understand whether the instrument (in this case, IA) has the potential to prevent the abuse of power or situations where the regulator is able to push through predetermined regulatory decisions. And finally, questions should be asked about issues such as education and learning and whether the accountability arrangement involves effective feedback mechanisms to stimulate a degree of reflexivity and self-criticism (Bovens 2007).

\section{Analysis}

\section{Procedural Assessment of IA}

As mentioned earlier, our analytical approach has revealed three categories of regulatory episode reflecting the degree to which they embed procedures that facilitate the three accountability phases, i.e. information, debate and judgement (Bovens 2006, 2007) (see Table 1).

\section{Episodes Involving No IA}

As shown in Table 1, the first group comprises 7 (out of 43) episodes where no IA was performed. The absence of IA was usually justified by the FRC in an accompanying statement suggesting that the policy proposals were not seen as imposing any additional regulatory burden warranting an impact assessment. However, our review of the nature of the episodes in this group reveals many related to new or significantly revised regulation, and hence the expectation would be that those would need to be subjected to IA. It has to be noted, however, that the majority of the episodes were initiated during the early stages of IA adoption and the subsequent pattern of application may be taken to indicate a growing commitment to the use of IA in more recent years.

\section{Episodes Involving Partial IA}

The second, largest group of episodes (24 out of 43) exemplifies partial utilization of IA as an accountability tool as it contains reference to some but not all accountability-enhancing elements of the instrument discussed in the previous section. Table 1 provides an analysis of which accountability-enhancing elements of IA (outlined in the analytical framework above) are present in relation to every episode in the group. It shows, in particular, the FRC's primary focus on the elements of IA relating to the information and debating phases of accountability and the absence of consideration of the judgement phase, that is, attempts to provide a convincing justification for the selection of the preferred policy option. Importantly, our analysis reveals that, even where relevant IA elements are present, the extent of their application, represented in the procedural detail with which they are addressed, falls short of the objectives of IA. It has to be recognized, however, that the level of procedural execution of the relevant IA steps has improved during the period under study, with episodes concluded in later years usually featuring a more sophisticated presentation and analysis. The discussion below will provide a detailed, narrative procedural assessment of examples of the episodes in the second group to demonstrate the extent to which IA serves to address the three accountability phases.

(i) With regards to the information phase of accountability (Bovens 2006, 2007), many episodes in the group fail to provide adequate information about the policy options considered. One significant weakness, for example, is the quantification of costs and benefits (i.e. economic impacts). Although the issue of cost is recognized in a large number of episodes, the published documents often lack detailed analysis 
Table 1 An overview of the use of IA as an accountability tool

\begin{tabular}{|c|c|c|c|c|}
\hline & \multirow[t]{2}{*}{ Regulatory episode } & \multicolumn{3}{|c|}{ Analysis of the use of IA } \\
\hline & & $\begin{array}{l}\text { No reference } \\
\text { to IA }\end{array}$ & $\begin{array}{l}\text { Partial (covers some } \\
\text { accountability-related } \\
\text { elements of IA) }\end{array}$ & $\begin{array}{l}\text { Full (covers all } \\
\text { accountability-related } \\
\text { elements of IA) }\end{array}$ \\
\hline 1 & Heritage Assets & & Information/Debate & \\
\hline 2 & FRS 20 & None & & \\
\hline 3 & FRSEE & None & & \\
\hline 4 & FRS 17 & & Information/Debate & \\
\hline 5 & FRS 25 & & Information/Debate & \\
\hline 6 & Half Year Financial Reports & None & & \\
\hline 7 & FRS 3 & & Information/Debate & \\
\hline 8 & $\begin{array}{l}\text { Statement of principles for Financial Reporting: } \\
\text { Interpretation for Public Benefit Entities }\end{array}$ & None & & \\
\hline 9 & FRS 8 & & Information/Debate & \\
\hline 10 & FRS 26 & & Information/Debate & \\
\hline 11 & FRS 20_2 & & Information/Debate & \\
\hline 12 & $\begin{array}{l}\text { Improvements to Financial Reporting Standards } \\
2008\end{array}$ & & Information/Debate & \\
\hline 13 & FRS 29 & & Debate & \\
\hline 14 & FRS 2, FRS 6 and FRS 28 & & Information/Debate & \\
\hline 15 & $\begin{array}{l}\text { Improvements to Financial Reporting Standards } \\
2009\end{array}$ & & Information/Debate & \\
\hline 16 & UIFT Abstract 42 and FRS 26 & & Information/Debate & \\
\hline 17 & The Future of UK GAAP/FRS 100, 101 and 102 & & & All \\
\hline 18 & FRS $25 \_2$ & & Information/Debate & \\
\hline 19 & $\begin{array}{l}\text { Improvements to Financial Reporting Standards } \\
2010\end{array}$ & & Information/Debate & \\
\hline 20 & FRS 29_2 & & Debate & \\
\hline 21 & ESRA & & Information/Debate & \\
\hline 22 & ISRE 2410 & & Information/Debate & \\
\hline 23 & SIR 5000 & None & & \\
\hline 24 & SIR 2000 & None & & \\
\hline 25 & ISA 600 (UK and Ireland) & & Information/Debate & \\
\hline 26 & ISA 700 (UK and Ireland) & & Information/Debate & \\
\hline 27 & ISA 700 (UK and Ireland) Revised & & Information/Debate & \\
\hline 28 & Ethical Standards for Auditors & & Information/Debate & \\
\hline 29 & Ethical Standards for Auditors 2 & None & & \\
\hline 30 & ISA Clarity Project & & & All \\
\hline 31 & $\begin{array}{l}\text { Changes to ISA } 260,570 \text { and } 700 \text { in response to } \\
\text { Sharman Panel Recommendations }\end{array}$ & & Information/Debate & \\
\hline 32 & FRS 103 & & & All \\
\hline 33 & FRC Abstract 1 & & & All \\
\hline 34 & FRS 102 (Revised) & & Debate & \\
\hline 35 & FRSSE (effective from 2008) (Revised) & & & All \\
\hline 36 & FRS 101 (Revised) & & & All \\
\hline 37 & FRS 102 (Revised) & & & All \\
\hline 38 & FRS 102 (Revised) & & & All \\
\hline
\end{tabular}


Table 1 continued

\begin{tabular}{|c|c|c|c|c|}
\hline & \multirow[t]{2}{*}{ Regulatory episode } & \multicolumn{3}{|c|}{ Analysis of the use of IA } \\
\hline & & $\begin{array}{l}\text { No reference } \\
\text { to IA }\end{array}$ & $\begin{array}{l}\text { Partial (covers some } \\
\text { accountability-related } \\
\text { elements of IA) }\end{array}$ & $\begin{array}{l}\text { Full (covers all } \\
\text { accountability-related } \\
\text { elements of IA) }\end{array}$ \\
\hline 39 & FRS 104 & & & All \\
\hline 40 & FRS 101 (Revised) & & Debate & \\
\hline 41 & Implementation of EU Accounting Directive & & & All \\
\hline 42 & FRS 102 (Revised) & & & All \\
\hline 43 & Client Asset Assurance Standard & & & All \\
\hline
\end{tabular}

and developed categorization of costs and offer only limited measurement. In the majority of cases, costs are acknowledged simply as something on which one needs to keep a watchful eye. In several accounting episodes cost is covered by a somewhat generic statement that "[i]n the ASB's view, the proposals should not impose significant additional costs of preparation" (for example, Amendment to FRS 25, Episode 18) but followed by an accompanying point that the ASB "believes that the amendments will result in information which is of benefit to users of financial statements" or a conclusion that "the cost of the proposed new requirements will not be disproportionate to their benefit". These documents thus acknowledge the potential for costs to be incurred but offer only a simple reasoned argument or statement of belief that the policy is appropriate without any supporting analysis. In addition, while the direct cost of compliance with the proposed regulation (for example, an increase in the amount of audit work) may be identified, second-order effects of such proposals (for example, on market conditions and economic development) are almost entirely ignored. An illustrative exception to this point is the development of Standard for Investment Reporting (SIR) 5000 (Episode 23), where reference is made to the potential cost on the functioning of the financial markets, but it is simply concluded that the "incurring of undue additional costs [...] [was] a low risk".

Likewise, attempts to identify the benefits from proposed regulations can be observed in only a handful of episodes in this group. In such cases benefits were usually identified by generic references to the expected improvement in the standard of financial reporting and auditing practice, rigorousness of internal processes, and ultimately, the quality of their outcomes. Some cases discussed benefits linked to the objective of minimizing the cost burden on the recipients of regulation, e.g. auditors. An example is the statement that "auditors may find it necessary to advance in time some procedures that would otherwise be performed later in the year for the audit of the next annual financial statements", which "would increase the costs attributable to the review but these should be offset by a related reduction in costs attributable to the year-end audit" (Exposure Draft for ISRE 2410 (Episode 22)). However, any benefits identified are discussed mainly in terms of the intended effect of a policy option and not in terms of the quantified economic value of this effect. The absence of quantified values for costs and benefits associated with policy options illustrates the limited nature of information about the policy alternatives supplied by the regulator (FRC). This is likely to mean that the FRC's accountability forum members will encounter significant difficulties when trying to assess the appropriateness of the regulator's decisions and policy choices, given that such an assessment should, in principal, be based on the comparative overview of economic impacts of the regulatory proposals considered (Bovens 2007).

(ii) As far as the debating phase is concerned, our analysis indicates a presence of public consultation in all episodes in this group (see Table 1). However, there is evidence that consultation is often used not as a means of providing transparency on the nature of information supporting regulatory decision-making but rather as a means to obtain this information. Specifically, the text of consultation papers and exposure drafts often contain not only invitations to comment on the existing policy proposals but also to effectively participate in supplying knowledge that the regulator can then use to properly articulate the policy alternatives. A specific example of this type of approach is contained in the following extract:

\section{Regulatory Impact}

6. In the ASB's view, the proposals set out in this FRED [Financial Reporting Exposure Draft-authors] should not impose significant additional costs of preparation. The ASB believes that the amendments will result in information 
which is of benefit to users of the financial statements. The $A S B$, however, would welcome views on whether there are any significant costs resulting from these proposals and, if so whether they can be quantified. The ASB would also welcome views on whether the benefits arising from the proposals in this FRED outweigh the costs involved.

\section{Invitation to Comment}

Question 5 The ASB considers the benefits of implementing the proposals in this FRED outweigh the costs involved. Do you agree? If not, why not? It would be helpful if any significant cost that would arise on implementation of the proposals could be identified and quantified. (Extracts from FRED: Improvements to Financial Reporting Standards 2009 (Episode 15))

This somewhat routinized approach found in most policy proposals highlights that reliance is placed on the principle of consultation mainly to serve reputational objectives. It may also suggest recognition of the need to adhere to, and demonstrate adherence to, the principles of accountability and transparency through an open debate but only by acknowledging the issue in a relatively formulaic and limited way.

(iii) The above potential weaknesses regarding the provision of information comprehensively detailing the economic impacts of policy options considered have a detrimental effect on the functionality of the judgement phase of accountability (Bovens 2007), and specifically, the possibility for the accountability forum to make informed judgments about the appropriateness of the regulator's decisions and claims. In particular, no episodes in this group (see Table 1) show evidence of FRC following step 5 of the IA process, which involves providing a rationalization for the selection of the preferred policy alternative. One example is Episode 25 that has to do with a regulatory response to the issuance by the IAASB (International Auditing and Assurance Standards Board) of a clarified version of ISA (International Standard on Auditing) 600. In a Discussion Paper, the regulator seeks stakeholders' comments on three possible actions: (1) early adoption of the ISA; (2) converting the Standard to a (non-binding) Practice Note, a form of document usually used to illustrate best practice rather than introduce new requirements; and (3) a nil option of delaying adoption until the IAASB implemented the full suite of clarified ISAs. The discussion of the options is then followed by an analysis of their likely benefits and quantified measures of cost.
However, the IA documents contain no attempt to develop, on the basis of that discussion, an evidence-based rationalization of the thought processes in support of its preferred policy. What may partly explain FRC's reluctance, at least in relation to some episodes, to utilize IA as a means to provide greater clarity on the regulatory rationale is the fact that, in many such cases, there is only really one available policy option that is realistic, for example, in the case of adoption of international standards to which there is already a general commitment or legal requirement. Therefore, the requirement to satisfy the need for IA is itself problematic and it can be difficult to see precisely on what basis informed discussion of policy options can take place.

\section{Episodes Involving Full IA}

In the last group of episodes ( 12 out of 43 , see Table 1 ) are those that cover a full range of accountability-related elements of IA and hence represent more comprehensive attempts to utilize IA as an accountability instrument. The number of such episodes has increased during the period under study. This may indicate a growing perceived importance of IA in the FRC's regulatory process in general and, in particular, a greater emphasis on the potential of IA for enhancing the agency's accountability and legitimacy. We have selected one episode in this group for a detailed discussion on the basis that it relates to one of the most significant policy projects undertaken by FRC during the period studied - the Future of UK Generally Accepted Accounting Principles (GAAP). The discussion is designed to not only illustrate a changing commitment to IA from a procedural perspective but also to demonstrate that challenges still remain in applying IA to the context of financial reporting regulation, even in cases where IA is given a full and comprehensive consideration.

The Future of UK GAAP episode concerns the future regime of national accounting standards in the light of convergence with International Financial Reporting Standards (IFRS), and particularly the requirements that should apply to smaller- and medium-sized enterprises (Episode 17). This is an area of particular significance for financial reporting as it involves the question of maintaining separate national accounting standards and the applicability of IFRS beyond listed entities. As a consequence, it has not been an easy area to regulate. The history of the ASB's consideration in this case has involved several discussion documents, consultations and exposure drafts and can be traced back to a Discussion Paper issued in 2004, which provided a wide ranging consideration of the issue but 
contained only limited reference to anything specifically relating to identified costs, benefits or burdens. At this stage the FRC was only adopting its new Regulatory Strategy and IA may not have been a major consideration in the development of the Discussion Paper.

A more recent Consultation Paper in 2009 went further in trying to identify the number of entities that could be affected by different national GAAP requirements and the invitation to comment included a request for identification of both costs and benefits. That consultation was followed by two Exposure Drafts (FREDs 43 and 44) in 2010 which proposed that a three-tier financial reporting framework would apply to different types and sizes of entity based on a concept of "public accountability". The FREDs incorporated a draft impact assessment at some 75 pages in length which was accompanied by outreach activities involving meetings with audit firms, preparers, investors and others to raise awareness of the proposals. The outcome of that consultation was that in 2011 ASB indicated that it was re-deliberating its proposals. The concept of public accountability was dropped but the underlying ideas of a tiered system of requirements and of reduced disclosure for certain enterprises would continue to be followed. In January 2012, three new exposure drafts (FREDs 46, 47 and 48) were published, incorporating a revised and reduced impact assessment. Three new standards were issued in late 2012 (FRSs 100 and 101) and early 2013 (FRS 102) to implement the proposals in the exposure drafts, together with a final IA document which (apart from some changes to refer to standards rather than drafts and the use of terminology of "cost-benefit analysis" rather than "evidence") largely replicated the content of the revised IA accompanying the January 2012 FREDs.

As noted above, the proposals exposed in 2010 were accompanied by a very detailed IA. Notable features of the draft IA include a discussion of alternative courses of action and why they are considered inappropriate, identification of costs associated with each of the policy alternatives, and a detailed discussion of benefits (although it is also stated that the benefits are impossible to quantify in a realistic way). Overall, it is concluded that the benefits outweigh the costs of the proposals. It is apparent that a considerable amount of effort had been devoted to trying to conduct the IA in a detailed, systematic and appropriate way. Notwithstanding that degree of development of IA, the responses to FRC proposals from the stakeholders (who can be considered to constitute members of the accountability forum-Bovens $(2006,2007))$ forced the regulator to rethink at least some aspects of its intended policy and significant changes were reflected in the proposals brought forward in the January 2012 FREDs, including dropping the concept of public accountability as a basis for differentiating entities.
Although the above process may suggest that the incorporation of the IA in the public consultation was seen by some members of the FRC's accountability forum as a means to influence policy development, such a view was not universally shared. This is clearly evident from the Feedback Statement associated with the revised IA document published in 2012, which presented stakeholder responses to a number of specific questions designed to capture their views of the IA itself (see Table 2 for a summary of responses). It is striking that only a minority of commentators chose to submit a response to the IA questions, suggesting that most did not regard the IA as the critical basis on which to either evaluate the proposals or make representations for alternatives. Further, within the minority of commentators who did address the IA questions, it is apparent that only small proportions expressed agreement with the propositions put forward by ASB making reference to the IA as support for their proposals.

A notable feature of the revised IA which accompanied the 2012 exposure drafts and 2012/13 standards is that it is a significantly shorter document (compared to the 2010 draft) and adopts a different approach to the presentation of evidence on costs and benefits. The FRC's approach to identifying and measuring costs and the discussion of benefits changes radically. Although some additional scenarios of impact on different types of reporting organization are introduced, none of them includes quantified estimates of costs, and the illustrative scenarios are moved from the main evidence text to an appendix. The discussion includes a statement that "it is not possible to determine with any degree of accuracy an average cost or even a meaningful range of costs for entities implementing the Standards" (Impact Assessment 2013, para 6.12). Somewhat paradoxically, however, the FRC goes on to refer to the total estimated cost of $£ 80 \mathrm{~m}$ calculated in the original (2010) IA. The approach to the evaluation of benefits is also significantly different and the amount of discussion of economic factors such as the impact of new information on companies' cost of capital in largely removed.

The differences between the original (2010) IA and the revised IA accompanying the 2012 and 2013 documents, and particularly the move away from detailed quantification, may indicate the intention of the FRC to avoid having to defend (being held accountable for) financial estimates that could be criticized as speculative as the justification of its policy choice, or creating a basis whereby the decisions reached could be challenged more explicitly. This raises concerns not only about the manner in which IA is used to support the information phase of regulatory accountability but also about the extent to which it can be relied upon by the accountability forum in their judgements about the validity of the regulator's actions and decisions (the judgment phase) (Bovens 2007). Furthermore, this episode also 


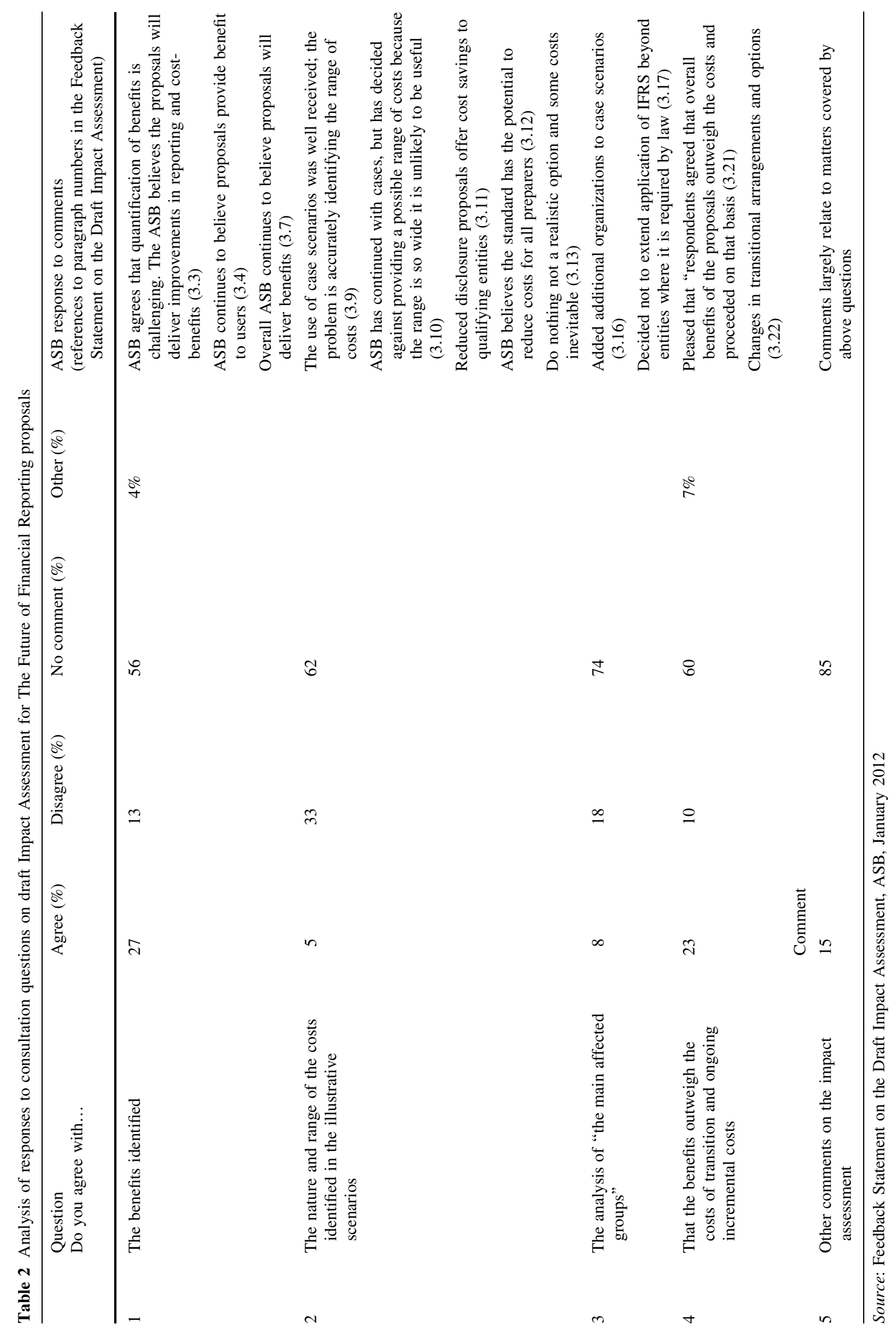


demonstrates that the FRC places significant reliance on the principle of public consultation, arguably to demonstrate commitment to the debating element of accountability. It appears, however, that the purpose of consultation is mainly to demonstrate participation, and to convey an impression that policy recipients are listened to. This kind of approach is also evident in many other episodes (e.g. Episodes 35-43) (see Table 1). However, as Bovens (2007) argues, participation alone does not constitute a genuine form of accountability as it often lacks "the element of justification, judgement and consequences" (p. 453). This observation is particularly relevant to FRC because, as this and other episodes analysed show, the duty to provide information is often delegated to members of the accountability forum, and particularly public practice accountancy firms as the main recipients of regulation. Consultation processes give a rather limited degree of clarity on the thought process behind the regulatory changes proposed. In other words, rather than facilitating a debate on the appropriateness of regulatory choices, the instrument of IA is relied upon as a means of articulating those choices. Our analysis shows in this regard that, particularly in case of more recent regulatory episodes (e.g. Episodes 35-43), the FRC opted for what might be called "consultation stage impact assessment" providing rather limited information relating to the costs and benefits of regulatory options considered and looking to policy stakeholders to supply much of this information.

\section{Systemic Assessment of IA as a Regulatory Accountability Tool}

The findings of the procedural evaluation of IA as an accountability instrument presented in the previous section point to a trend towards a more routine and also, at least in relation to some episodes, more sophisticated use of the instrument within FRC during the period analysed, which suggests a growing momentum for IA. However, the findings also give rise to a number of systemic issues and concerns. Specifically, we have not found evidence to establish conclusively that IA does indeed deliver on its objectives by producing better, more accountable and transparent governance practices. If anything, our findings seem to point to the opposite, that, in the words of Coletti and Radaelli (2013, p. 1065), IA is used to "change ends with the means" or, in other words, to create a perception of accountability by presenting a growing use of IA as a main objective. Our analysis reveals, for example, that, even where IA is formally embedded in the policy process (Groups 2 and 3 in the above analysis), a closer assessment of the extent of execution reveals partial application and what looks like a box-ticking exercise rather than a meaningful utilization of IA as an accountability instrument. Furthermore, another systemic feature of the IA process within FRC is its heavy reliance on public consultation (also noted in the review of the FRC's IA practices by the UK's regulatory oversight executiveBRE 2010). Consultation procedures may lead to greater accountability through enhanced answerability and observability of the process of policy making (Jordana et al. 2015; Bovens 2006, 2007; Mulgan 2003) and facilitate a dialogue between the regulator and forum actors. However, the manner in which consultation is administrated by FRC indicates a possibility that IA may be used to project a desired image rather than to enhance stakeholder participation. Jordana et al. (2015) argue that, to operate as meaningful accountability mechanisms, consultation processes "must go beyond sheer information and include debate, namely the possibility of posing questions by the respective accountability forum and providing responses" (p. 8). Our analysis indicates that FRC does see consultation as a formal means for collecting stakeholder feedback but makes limited attempt to show how those opinions collected have actually been addressed during policy deliberation and with what consequences for the content of policy outcomes. It is plausible that the low level of stakeholder participation during consultation evident in some regulatory episodes analysed (such as the Future of the UK GAAP) is a direct consequence of this approach by FRC.

The inconsistent content of information communicated to forum members through the use of IA presents another factor hindering the possibility of an effective dialogue between them and the regulator. Examples include the lack of consideration of alternative courses of action (policy options) and the difficulties with providing measured assessments of the economic impacts of regulation. Also, even where this type of cost-benefit analysis is present, it tends to focus predominantly on the consequences for particular members of the forum, most notably accounting practitioners, to the exclusion of other, possibly significant "second-order" impacts on, for example, the users of accounting/audit reports or indeed the broader economy. This approach seems to be in conflict with one of the central arguments for IA that by making costs and benefits explicit the interests of all entities subject to regulation are accounted for (Renda 2006).

Weaknesses in the information element of accountability (Bovens 2007) administered through IA limit significantly the capacity of IA to become an effective tool for enhancing forum members' substantive understanding of the regulator's conduct, its approach to policy formulation, and the likely consequences of its policies. These observations echo Bovens's (2007) contention that the potential of an accountability instrument (such as IA) to enhance stakeholders' judgements about the regulator's conduct 
(the judgment phase of accountability) is directly and inextricably linked to the functionality of the other two (information and debating) phases. It has to be noted, however, that the extent to which IA provides a detailed "visualization" of the regulatory process so as to increase its transparency is not always solely a matter at the regulator's discretion. The often significant (human) cost of carrying out IA may detract from using the instrument in a comprehensive manner, especially in cases considered to be dealing with relatively insignificant policy issues.

The procedural assessment of IA as an accountability instrument also casts doubt as to its effectiveness as a tool for preventing the abuse of (legislative) power that, as Bovens (2006) noted, should be one of the desired systemic objectives of any accountability arrangement. Instead, our assessment shows that FRC's approach to IA may potentially indicate, at least in some cases, attempts to justify and provide a scientific underpinning to the predetermined policy decisions. These concerns echo those expressed by Schrefler $(2010,2013)$ (discussed earlier) which point to independent regulators often opting for what she terms "strategic substantiating" usage of knowledge and evidence (produced through IA) in support of the pre-selected policy options. While we do not discount the possibility that IA may also be utilized by FRC in a way which enhances the regulator's and the forum members' substantive understanding of the policy issues at hand (the instrumental use of IA described by Schrefler 2010, 2013), we also need to at least acknowledge other possible motivations, such as a focus on IA as an instrument to promote perceptions of the knowledge intensity of the regulatory process, critical for the legitimacy of independent regulatory actors.

Further, there is clearly scope for FRC to exercise much more reflection and self-criticism when applying IA so as to enable it to be a tool for "social learning" where policy makers as well as recipients of regulation "gain a clear sense of the options, and trade-offs" and understand and make judgements about the consequences of solutions (Jacobs 2006, p. 18). Our study may be taken as an empirical illustration of prior claims that an economic model of IA may potentially produce poor learning results (Coletti and Radaelli 2013). Nonetheless, it should be acknowledged that understanding, debating and judging the impact of policy measures in the area of financial reporting, which are themselves developed with a fair degree of abstraction, is a challenging task. This raises questions about the format of IA rules and, specifically, whether they should be designed in an abstract way which can address this complexity, irrespective of the policy context, actors, or issues at hand, or alternatively, contain carefully formulated definitions of preferred treatments to aid application. Resolving the principles vs. rules dilemma in the context of IA ultimately boils down to a balancing act between the risk of the assessment becoming a dull, overlyprescriptive and therefore artificial instrument and the need to gradually increase the usefulness of IA as a tool for making regulators answerable to their ultimate audiences by reducing the number of 'unknowns'.

\section{Conclusion}

This study adds to prior research which has examined the use and overall quality of IA in the context of governmental and inter-governmental agencies (Jacobs 2005 and 2006; Radaelli 2010; Dunlop et al. 2012) by providing a specific focus on the properties of IA as a regulatory accountability tool, with an emphasis on a non-governmental regulatory setting. Our analysis has involved both a procedural assessment of the execution of the accountability-enhancing elements of IA (outlined in our analytical approach in "Evidence Base and Analytical Approach to Assessing IA as an Accountability Tool" section) and a more systemic evaluation of the roles of IA as an accountability tool within FRC. In particular, we have combined a general assessment of the execution of the accountability-related steps of IA in all episodes identified with a more nuanced, narrative discussion of individual episodes. This has enabled us to analyse the extent of IA application and to show more clearly that, even where all relevant steps were formally identified in IA discussions in the FRC documents published in connection with individual episodes, the procedural quality of execution of those steps varied considerably. In particular, we have reported shortcomings relating to issues such as the provision of reliable and complete information about the rationale behind policy decisions and the regulator's over-reliance on public consultation procedures. In summary, our findings suggest that the direct contribution of IA to enhancing FRC's accountability has been limited. While the FRC has recognized the imperative for IA, the practicalities and difficulties of implementation have led to numerous weaknesses in its application.

Our findings contribute to both accountability and IA literatures in a number of ways. Firstly, our study directly responds to calls for a better understanding of accountability arrangements in a regulatory setting. Prior literature has described a lack of research into the functionality of those arrangements as "paradoxical", specifically in the context of new delegated forms of regulation, and has pointed out the importance of "both wider democratic control and closer supervision by political representatives over these new modes of regulatory governance" (Jordana et al. 2015, p. 256). Claims of autonomy, independence, and knowledge intensity characteristic of private nongovernmental regulatory agencies have shaped greatly their approaches to accountability through, among other things, 
promoting a greater emphasis on output-focused instruments (Schrefler 2010; Jordana et al. 2015). Our study has subjected to scrutiny the practices and procedures by which regulatory accountability is enabled by reference to one such instrument and, by doing so, contributed some further insights to add to a growing academic debate into regulatory accountability not only as a virtue but also an object of analytical enquiry (Bovens 2006, 2007; Jordana et al. 2015; Righettini and Grimaldi 2015).

Secondly, we have provided a nuanced rationalization and empirical illustration of IA in terms of its capacity to enhance regulatory accountability. While the IA literature has provided convincing explanations of the various uses of IA (Radaelli 2010; Dunlop et al. 2012), the accountability-related properties of the instrument and the role that it can play in facilitating broader transparency and answerability have not been explored in great depth. In particular, we have shown how IA is capable of contributing to all three elements identified in prior literature as essential components of an effective accountability relationship, namely information, debate and justification (Mulgan 2003; Bovens 2006, 2007; Jordana et al. 2015). However, despite these capabilities implicit in IA, the case of FRC demonstrates that the meaning of accountability is fluid and subject to interpretation, as regulators seek to emphasize the importance of particular accountability elements depending on their specific objectives and constraints. The presence of public consultation in the majority of episodes analysed and, at the same time, the pervasive lack of clarity on either the supporting evidence for or the subsequent impact of those consultation procedures on policy point to FRC prioritizing the social (debating) aspects of accountability while downplaying the importance of the other two elements (information and justification). While there is evidence emerging of a more comprehensive use of IA within FRC in recent years, considerate remains premature to conclude that this offers a complete "accountability relationship" administered through IA (Mulgan 2003).

Lastly, our findings provide an insight into the dynamics of IA in a non-governmental regulatory setting largely overlooked in the prior IA literature, which has focused primarily on governmental and cross-governmental organizations (with a few exceptions-see, for example, Fraas and Lutter 2011). While our findings echo those by Fraas and Lutter (2011) who reported a tendency for mechanical application of IA for the purposes of regulatory compliance among independent regulators in the U.S (Fraas and Lutter 2011 , p. 2), we offer important additional insights into the particular motivations behind IA in a non-governmental regulatory context. In particular, the focus on IA has enabled us to show the particular procedures through which IRAs seek to convince their forum members of the inherent knowledge-intensity of their policy making, which is critical to their public acceptance and authority (Maggetti 2010). Our analysis reveals the procedural limitations in the implementation of IA as a knowledge resource and the predominantly strategic rationales (Schrefler 2010, 2013) underpinning its use. In particular, the often formulaic approach to evidence gathering administered as part of the IA process points to a possibility that IA may be used to validate predetermined policy decisions and reduce the likelihood of those decisions being challenged either by the political principle (the relevant government executive body) or stakeholders such as the groups subject to regulation. While this potentially points to the strong motivation for IA as an instrument for greater political acceptance, the possibility of instrumental use of IA (to enhance the regulator's and the forum members' substantive understanding of the policy issues) should not be discounted (Schrefler 2010). That possibility clearly depends on the regulator's ability to obtain and intelligibly process knowledge but, as the case of the FRC demonstrates, can be constrained substantially by the very nature of the policy dilemmas and, particularly, the principles-based nature of financial reporting regulation. The contribution of IA to regulatory decision-making is affected by the inherent limitations of the instrument as well as the manner of its application by a regulatory agency. The ideals and principles underlying political commitment to IA may themselves be valid, but the realities of IA implementation highlight a discrepancy between what IA prescribes and what is achievable in principle, making IA a limited tool for regulatory accountability in the context of independent regulation of accounting and auditing.

\section{Compliance with Ethical Standards}

Conflict of interest There is no conflict of interest involved in either carrying out or reporting the findings of this study.

Ethical approval This study relies primarily on the analysis of documentary materials in the public domain, and where necessary the authors received consent from the organization under study (the Financial Reporting Council in the UK) to access and review these documents.

Informed consent We also draw on a small number of interviews with FRC staff, and we can confirm that those interviews were carried out in accordance with the ethics guidelines of our home institution and also with the 1964 Helsinki Declaration and its latter amendments. Also, an informal consent was obtained from all the individuals interviewed for this study.

Open Access This article is distributed under the terms of the Creative Commons Attribution 4.0 International License (http://creative commons.org/licenses/by/4.0/), which permits unrestricted use, distribution, and reproduction in any medium, provided you give appropriate credit to the original author(s) and the source, provide a link to the Creative Commons license, and indicate if changes were made.

\section{Appendix}

See Table 3. 
Table 3 Regulatory episodes and related policy documents

\begin{tabular}{|c|c|c|c|}
\hline \multirow[t]{6}{*}{1} & \multicolumn{3}{|c|}{ Heritage Assets } \\
\hline & DP & January 2006 & Discussion Paper Heritage Assets: can accounting do better? \\
\hline & ED & December 2006 & Financial Reporting Exposure Draft Accounting for \\
\hline & & & Heritage Assets (FRED 40) \\
\hline & ED & June 2008 & Financial Reporting Exposure Draft Heritage Assets (FRED 42) \\
\hline & $\mathrm{S}$ & June 2009 & FRS 30 Heritage Assets \\
\hline \multirow[t]{3}{*}{2} & \multicolumn{3}{|c|}{ FRS 20} \\
\hline & ED & March 2006 & Amendment to FRS 20 (IFRS 2) Share-based Payment Vesting Conditions and Cancellations \\
\hline & S & March 2008 & Amendment to FRS 20 (IFRS 2) Share-based Payment Vesting Conditions and Cancellations \\
\hline \multirow[t]{5}{*}{3} & \multicolumn{3}{|c|}{ FRSSE } \\
\hline & ED & April 2006 & Amendment to FRSSE \\
\hline & S & January 2007 & FRSSE (effective January 2007) \\
\hline & $S$ & June 2008 & FRSSE (effective April 2008) \\
\hline & $\mathrm{S}$ & July 2013 & FRSEE (effective January 2015) \\
\hline \multirow[t]{4}{*}{4} & \multicolumn{3}{|c|}{ FRS 17} \\
\hline & ED & May 2006 & $\begin{array}{l}\text { Proposed Amendment to FRS } 17 \text { Retirement Benefits and Reporting Statement } \\
\text { Retirement Benefits-Disclosures }\end{array}$ \\
\hline & $\mathrm{S}$ & Dec 2006 & Amendment to FRS17 Retirement Benefits \\
\hline & RS & January 2007 & Reporting Statement Retirement Benefits-Disclosures \\
\hline \multirow[t]{4}{*}{5} & \multicolumn{3}{|r|}{ (2- } \\
\hline & ED & July 2006 & $\begin{array}{l}\text { Amendment to FRS } 25 \text { (IAS 32) Financial Instruments: Presentation Financial } \\
\text { Instruments Puttable at Fair Value and Obligations Arising on Liquidation }\end{array}$ \\
\hline & ED & March 2008 & $\begin{array}{l}\text { Proposed Amendment to FRS } 25 \text { Financial Instruments: Presentation Puttable } \\
\text { Financial Instruments and Obligations Arising on Liquidation }\end{array}$ \\
\hline & S & August 2008 & $\begin{array}{l}\text { Amendment to FRS } 25 \text { Financial Instruments: Presentation Puttable Financial } \\
\text { Instruments and Obligations Arising on Liquidation }\end{array}$ \\
\hline \multirow[t]{3}{*}{6} & \multicolumn{3}{|c|}{ Half-yearly financial reports } \\
\hline & ED & February 2007 & Statement Half-yearly financial reports \\
\hline & RS & July 2007 & Half-yearly financial reports \\
\hline \multirow[t]{4}{*}{7} & \multicolumn{3}{|c|}{ FRS 3} \\
\hline & ED & March 2007 & Proposed Amendment to FRS 3 Reporting Financial Performance \\
\hline & $\mathrm{CP}$ & April 2007 & Consultation Paper: IASB Exposure Draft of a proposed IFRS for SMEs \\
\hline & S & July 2007 & Amendment to FRS 3 Reporting Financial Performance \\
\hline \multirow[t]{4}{*}{8} & \multicolumn{3}{|c|}{ Statement of Principles for Financial Reporting: Interpretation for Public Benefit Entities } \\
\hline & DP & May 2003 & $\begin{array}{l}\text { Discussion Paper Statement of Principles for Financial Reporting: Proposed } \\
\text { Interpretation for Public Benefit Entities }\end{array}$ \\
\hline & ED & August 2005 & $\begin{array}{l}\text { Statement of Principles for Financial Reporting: Proposed Interpretation } \\
\text { for Public Benefit Entities }\end{array}$ \\
\hline & RS & June 2007 & $\begin{array}{l}\text { Interpretation of the Statement of Principles for Financial Reporting: } \\
\text { Interpretation for Public Benefit Entities }\end{array}$ \\
\hline \multirow[t]{4}{*}{9} & \multicolumn{3}{|r|}{${ }^{x}$} \\
\hline & ED & July 2007 & FRED 41 Related Party Disclosures \\
\hline & ED & October 2007 & Exposure Draft Amendments to FRS 26 (IAS 36) \\
\hline & S & December 2008 & Amendment to FRS 8 Related Party Disclosures: Legal Changes 2008 \\
\hline
\end{tabular}


Table 3 continued

\begin{tabular}{|c|c|c|c|}
\hline \multirow[t]{4}{*}{10} & \multicolumn{3}{|c|}{ FRS 26} \\
\hline & ED & October 2007 & Exposure Draft Amendments to FRS 26 (IAS 36) \\
\hline & ED & October 2007 & $\begin{array}{l}\text { Amendment to FRS } 20 \text { (IFRS 2) Share-based payment-Group } \\
\text { Cash-settled Share-based Payment Transactions }\end{array}$ \\
\hline & S & November 2008 & $\begin{array}{l}\text { Amendment to FRS } 26 \text { (IAS 39) Financial Instruments: } \\
\text { Recognition and Measurement Eligible Hedged Items }\end{array}$ \\
\hline \multirow[t]{3}{*}{11} & \multicolumn{3}{|c|}{ FRS 20_2 } \\
\hline & ED & January 2008 & $\begin{array}{l}\text { Amendment FRS } 20 \text { (IFRS 2) Share-based payment-Group } \\
\text { Cash-settled Share-based Payment Transactions }\end{array}$ \\
\hline & $S$ & August 2009 & $\begin{array}{l}\text { Amendment FRS } 20 \text { (IFRS 2) Share-based payment-Group } \\
\text { Cash-settled Share-based Payment Transactions }\end{array}$ \\
\hline \multirow[t]{3}{*}{12} & \multicolumn{3}{|c|}{ Improvements to Financial Reporting Standards 2008} \\
\hline & ED & June 2008 & FRED Improvements to Financial Reporting Standards \\
\hline & S & December 2008 & Improvements to Financial Reporting Standards \\
\hline \multirow[t]{3}{*}{13} & \multicolumn{3}{|c|}{ FRS 29} \\
\hline & ED & November 2008 & $\begin{array}{l}\text { Proposed Amendments to FRS } 29 \text { (IFRS 7) Financial Instruments } \\
\text { Disclosures-Improvements to Financial Instruments Disclosures. }\end{array}$ \\
\hline & S & May 2009 & Amendments to FRS 29 'Improving Disclosures about Financial Instruments' \\
\hline \multirow[t]{3}{*}{14} & \multicolumn{3}{|c|}{ FRS 2, FRS 6, and FRS 28} \\
\hline & ED & December 2008 & $\begin{array}{l}\text { Amendments to FRS } 2 \text { Accounting for Subsidiary Undertakings, } \\
\text { FRS } 6 \text { Acquisitions and Mergers, and FRS } 28 \text { Corresponding Amounts }\end{array}$ \\
\hline & $\mathrm{S}$ & June 2009 & Amendments to FRS 2, FRS 6, and FRS 28 \\
\hline \multirow[t]{3}{*}{15} & \multicolumn{3}{|c|}{ Improvements to Financial Reporting Standards 2009} \\
\hline & ED & June 2009 & FRED Improvements to Financial Reporting Standards 2009 \\
\hline & $\mathrm{S}$ & December 2009 & Improvements to Financial Reporting Standards 2009 \\
\hline \multirow[t]{3}{*}{16} & \multicolumn{3}{|c|}{ UITF Abstract 42 and FRS 26} \\
\hline & ED & June 2009 & $\begin{array}{l}\text { FRED Proposed Amendments to UITF Abstract } 42 \text { and FRS } 26 \\
\text { (IAS 39) Embedded Derivatives }\end{array}$ \\
\hline & S & September 2009 & $\begin{array}{l}\text { Amendments to UITF Abstract } 42 \text { and FRS } 26 \text { (IAS 39) } \\
\text { Embedded Derivatives }\end{array}$ \\
\hline \multirow[t]{11}{*}{17} & \multicolumn{3}{|c|}{ The Future of UK GAAP } \\
\hline & $\mathrm{CP}$ & August 2009 & Policy Proposal: The Future of UK GAAP \\
\hline & ED & October 2010 & $\begin{array}{l}\text { The Future of Financial Reporting_-Part One: Explanation FRED } 43 \\
\text { Application of Financial Reporting Standards \& FRED } 44 \text { Financial } \\
\text { Reporting for Medium-sized Entities }\end{array}$ \\
\hline & ED & October 2010 & The Future of Financial Reporting_-Part Two: Draft Financial Reporting Standards \\
\hline & ED & October 2010 & The Future of Financial Reporting-Appendices \\
\hline & ED & March 2011 & FRED 45 Financial Reporting Standard for Public Benefit Entities (FRSPE) \\
\hline & ED & January 2012 & $\begin{array}{l}\text { Revised Exposure Drafts FRED } 46 \text { Application of Financial Reporting } \\
\text { Requirements, FRED } 47 \text { Reduced Disclosure Framework \& FRED } 48 \\
\text { The Financial Reporting Standard applicable in the UK and Republic of Ireland }\end{array}$ \\
\hline & S & November 2012 & $\begin{array}{l}\text { FRS } 100 \text { Application of Financial Reporting Requirements } \\
\text { (and consequential amendments to FRSSE; FRS101 Reduced Disclosure Framework }\end{array}$ \\
\hline & S & March 2013 & FRS 102 The Financial Reporting Standard applicable in the UK and Republic of Ireland \\
\hline & IA & March 2013 & Impact assessment in relation to the issuance of FRS $100,101,102$ \\
\hline & FB & March 2013 & Feedback statement in relation to FRED 46,47 and 48 \\
\hline
\end{tabular}


Table 3 continued

\begin{tabular}{|c|c|c|c|}
\hline \multirow[t]{3}{*}{18} & \multicolumn{3}{|c|}{ FRS 25_2 } \\
\hline & ED & November 2009 & $\begin{array}{l}\text { FRED Proposed Amendment to FRS } 25 \text { (IAS 32) Financial } \\
\text { Instruments: Presentation-Classification of Rights Issues. }\end{array}$ \\
\hline & $\mathrm{S}$ & January 2010 & $\begin{array}{l}\text { Amendment to FRS } 25 \text { (IAS 32) Financial Instruments: } \\
\text { Presentation-Classification of Rights Issues }\end{array}$ \\
\hline \multirow[t]{3}{*}{19} & \multicolumn{3}{|c|}{ Improvements to Financial Reporting Standards 2010} \\
\hline & ED & June 2010 & FRED Improvements to Financial Reporting Standards 2010 \\
\hline & S & November 2010 & Improvements to Financial Reporting Standards 2010 \\
\hline \multirow[t]{3}{*}{20} & \multicolumn{3}{|c|}{ FRS 29_2 } \\
\hline & ED & February 2011 & $\begin{array}{l}\text { FRED Proposed Amendments to FRS } 29 \text { (IFRS 7) Financial } \\
\text { Instruments: Disclosures: Disclosures-Transfers of Financial Assets. }\end{array}$ \\
\hline & $\mathrm{S}$ & July 2011 & $\begin{array}{l}\text { Amendments to FRS } 29 \text { (IFRS 7) Financial Instruments: Disclosures: } \\
\text { Disclosures-Transfers of Financial Assets. }\end{array}$ \\
\hline \multirow[t]{4}{*}{21} & \multicolumn{3}{|c|}{$E S R A$} \\
\hline & DP & January 2006 & Exposure Draft Ethical Standards for Reporting Accountants \\
\hline & FB & 2006 & Feedback on Responses to Consultation \\
\hline & S & October 2006 & Ethical Standards for Reporting Accountants \\
\hline \multirow[t]{4}{*}{22} & \multicolumn{3}{|c|}{ ISRE 2410} \\
\hline & $\mathrm{ED}$ & January 2007 & $\begin{array}{l}\text { Exposure Draft: ISRE } 2410 \text { Review of Interim Financial Information } \\
\text { Performed by the Independent Auditor of the Entity. }\end{array}$ \\
\hline & FB & 2007 & Feedback on Responses \\
\hline & $\mathrm{S}$ & July 2007 & $\begin{array}{l}\text { ISRE } 2410 \text { Review of Interim Financial Information Performed by } \\
\text { the Independent Auditor of the Entity }\end{array}$ \\
\hline \multirow[t]{4}{*}{23} & \multicolumn{3}{|c|}{ SIR 5000} \\
\hline & ED & May 2007 & $\begin{array}{l}\text { ED of SIR } 5000 \text { Investment Reporting Standards Applicable to Public } \\
\text { Reporting Engagements on Financial Information Reconciliations }\end{array}$ \\
\hline & FB & February 2008 & Feedback on responses \\
\hline & $\mathrm{S}$ & February 2008 & $\begin{array}{l}\text { SIR } 5000 \text { Investment Reporting Standards Applicable to Public Reporting } \\
\text { Engagements on Financial Information Reconciliations }\end{array}$ \\
\hline \multirow[t]{4}{*}{24} & \multicolumn{3}{|c|}{ SIR 2000} \\
\hline & DP & September 2010 & $\begin{array}{l}\text { SIR } 2000 \text { Investment Reporting Standards Applicable to Public Reporting } \\
\text { Engagements on Historical Financial Information }\end{array}$ \\
\hline & FB & 2011 & Feedback on responses \\
\hline & $\mathrm{S}$ & March 2011 & $\begin{array}{l}\text { Revised SIR } 2000 \text { Investment Reporting Standards Applicable to Public } \\
\text { Reporting Engagements on Historical Financial Information }\end{array}$ \\
\hline \multirow[t]{3}{*}{25} & \multicolumn{3}{|c|}{ ISA 600 (UK and Ireland) } \\
\hline & DP & December 2007 & $\begin{array}{l}\text { Discussion of ISA } 600 \text { The work of Related Auditors and Other Auditors in } \\
\text { the Audit of Group Financial Statements }\end{array}$ \\
\hline & $\mathrm{S}$ & April 2008 & $\begin{array}{l}\text { ISA } 600 \text { (UK and Ireland) The work of Related Auditors and Other Auditors } \\
\text { in the Audit of Group Financial Statements }\end{array}$ \\
\hline \multirow[t]{6}{*}{26} & \multicolumn{3}{|c|}{ ISA 700 (UK and Ireland) } \\
\hline & DP & December 2007 & Auditor's Report: Time for Change? \\
\hline & FB & October 2008 & Feedback paper: Auditor's Report: Time for change? \\
\hline & ED & September 2008 & ED of ISA 700 (UK and Ireland) The Auditor's Report on Financial Statements \\
\hline & FB & September 2008 & Feedback paper on ED \\
\hline & S & March 2009 & ISA 700 (UK and Ireland) The Auditor's Report on Financial Statements \\
\hline
\end{tabular}


Table 3 continued

\begin{tabular}{|c|c|c|c|}
\hline \multirow[t]{7}{*}{27} & \multicolumn{3}{|c|}{ ISA 700 (UK and Ireland) Revised } \\
\hline & $\mathrm{ED}$ & September 2010 & $\begin{array}{l}\text { ED of ISA } 700 \text { (UK and Ireland) The Auditor's Report on } \\
\text { Financial Statements }\end{array}$ \\
\hline & FB & 2010 & Feedback paper on ED \\
\hline & S & February 2011 & $\begin{array}{l}\text { Amended ISA } 700 \text { (UK and Ireland) The Auditor's Report on } \\
\text { Financial Statements }\end{array}$ \\
\hline & DP & February 2013 & Revision to ISA 700 (UK and Ireland) \\
\hline & FS & June 2013 & Feedback paper on DP \\
\hline & S & June 2013 & $\begin{array}{l}\text { Revised ISA } 700 \text { (UK and Ireland) The Independent Auditor's } \\
\text { Report on Financial Statements }\end{array}$ \\
\hline \multirow[t]{4}{*}{28} & \multicolumn{3}{|c|}{ Ethical Standards for Auditors } \\
\hline & & Spring 07 & Review of Ethical Standards for Auditors \\
\hline & ED & October 2007 & Amendments to the Ethical Standards \\
\hline & $\mathrm{FB} / \mathrm{S}$ & April 08 & Feedback Paper on ED and Revised Ethical Standards. \\
\hline \multirow[t]{5}{*}{29} & \multicolumn{3}{|c|}{ Ethical Standards for Auditors 2} \\
\hline & ED & March 2009 & $\begin{array}{l}\text { ED of Revised Ethical Standards No. } 1 \text { Integrity, Objectivity and Independence, } \\
\text { No. } 2 \text { Financial, Business, employment and Personal Relationships, } \\
\text { No. } 3 \text { Long Association with the Audit Engagement, No. } 4 \text { Fees, } \\
\text { Remuneration and Evaluation policies, Litigation, Gifts and Hospitality, } \\
\text { No. } 5 \text { Non-audit Services Provided to Audited Entities }\end{array}$ \\
\hline & S & October 2009 & Revised Ethical Standard 3 Long Association with the Audit Engagement \\
\hline & FB & October 2009 & Feedback on Responses to March 2009 Consultation \\
\hline & S & July 2010 & $\begin{array}{l}\text { Revised Ethical Standards No. } 1 \text { Integrity, Objectivity and Independence, } \\
\text { No. } 2 \text { Financial, Business, employment and Personal Relationships, } \\
\text { No. } 4 \text { Fees, Remuneration and Evaluation policies, Litigation, } \\
\text { Gifts and Hospitality, No. } 5 \text { Non-audit Services Provided to Audited Entities }\end{array}$ \\
\hline \multirow[t]{6}{*}{30} & \multicolumn{3}{|c|}{ ISA Clarity project } \\
\hline & \multirow[t]{2}{*}{$\mathrm{DP}$} & October 2008 & $\begin{array}{l}\text { Consultation on whether UK and Irish auditing standards should } \\
\text { be updated for the new (clarified) ISAs. }\end{array}$ \\
\hline & & March 2009 & APB announces intention to update ISAs (UK and Ireland) \\
\hline & ED & April 2009 & ED of Clarified ISAs (UK and Ireland) \\
\hline & FB & October 2009 & Feedback on responses to ED. \\
\hline & $\mathrm{S}$ & October 2009 & Clarified ISAs (UK and Ireland) \\
\hline \multirow[t]{4}{*}{31} & \multicolumn{3}{|c|}{ Changes to ISA 260, 570 and 700 in response to Sharman Panel Recommendations } \\
\hline & DP & January 2013 & Implementing the Recommendations of the Sharman panel \\
\hline & FB & November 2013 & Implementing the Recommendations of the Sharman panel \\
\hline & $\mathrm{S}$ & September 2014 & ISA 260,570 and 700 (Revised) \\
\hline \multirow[t]{4}{*}{32} & FRS 103 & & \\
\hline & ED & July 2013 & FRED 49 Draft FRS 103 Insurance Contracts \\
\hline & ED & July 2013 & Exposure Draft of Implementation Guidance to accompany FRC 103 \\
\hline & IA, FB & March 2014 & Impact Assessment and Feedback Statement for FRS 103 \\
\hline
\end{tabular}


Table 3 continued

\begin{tabular}{|c|c|c|c|}
\hline \multirow[t]{3}{*}{33} & \multicolumn{3}{|c|}{ FRC Abstract 1} \\
\hline & DP & August 2013 & $\begin{array}{l}\text { FRED } 50 \text { Draft FRC Abstract } 1 \text { Residential Management } \\
\text { Companies' Financial Statements }\end{array}$ \\
\hline & IA, FB & July 2015 & $\begin{array}{l}\text { Impact Assessment and Feedback Statement relating to } \\
\text { FRED 50,57, 58,59,60 and } 61\end{array}$ \\
\hline \multirow[t]{2}{*}{34} & \multicolumn{3}{|c|}{ FRS 102 (Revised) } \\
\hline & ED & November 2013 & $\begin{array}{l}\text { FRED } 51 \text { Draft Amendments to FRS } 102 \text { The Financial Reporting } \\
\text { Standard applicable in the UK and Republic of Ireland: Hedge Accounting }\end{array}$ \\
\hline \multirow[t]{4}{*}{35} & \multicolumn{3}{|c|}{ FRSSE (effective from 2008) (Revised) } \\
\hline & ED & December 2013 & FRED52 Draft Amendments to FRSSE (effective 2008) Micro-entities \\
\hline & IA & April 2014 & Impact Assessment and Feedback Statement \\
\hline & S & April 2014 & FRSSE (Revised) (effective January 2015) \\
\hline \multirow[t]{4}{*}{36} & \multicolumn{3}{|c|}{ FRS 101 (Revised) } \\
\hline & ED & December 2013 & FRED 53 Draft Amendments to FRS 101 Reduced Disclosure Framework \\
\hline & IA, FB & July 2014 & Impact Assessment and Feedback Statement \\
\hline & S & July 2014 & FRS 101 (Revised) Reduced Disclosure Framework \\
\hline \multirow[t]{4}{*}{37} & \multicolumn{3}{|c|}{ FRS 102 (Revised) } \\
\hline & ED & February 2014 & $\begin{array}{l}\text { FRED } 54 \text { Draft Amendments to FRS } 102 \text { The Financial Reporting } \\
\text { Standard applicable in the UK and Republic of Ireland: Basic } \\
\text { Financial Instruments }\end{array}$ \\
\hline & IA & July 2014 & Impact Assessment \\
\hline & $\mathrm{S}$ & July 2014 & $\begin{array}{l}\text { FRS } 102 \text { (Revised) The Financial Reporting Standard applicable } \\
\text { in the UK and Republic of Ireland }\end{array}$ \\
\hline \multirow[t]{4}{*}{38} & \multicolumn{3}{|c|}{ FRS 102 (Revised) } \\
\hline & ED & August 2014 & $\begin{array}{l}\text { FRED } 55 \text { Draft Amendments to FRS } 102 \text { The Financial Reporting } \\
\text { Standard applicable in the UK and Republic of Ireland: Pension Obligations }\end{array}$ \\
\hline & $\mathrm{IA}, \mathrm{FB}$ & February 2015 & Impact Assessment and Feedback Statement \\
\hline & $\mathrm{S}$ & February 2015 & $\begin{array}{l}\text { FRS } 102 \text { (Revised) The Financial Reporting Standard applicable in } \\
\text { the UK and Republic of Ireland }\end{array}$ \\
\hline \multirow[t]{4}{*}{39} & \multicolumn{3}{|c|}{ FRS 104} \\
\hline & ED & November 2014 & FRED 56 Draft FRS 104 Interim Financial Reporting \\
\hline & $\mathrm{IA}, \mathrm{FB}$ & March 2014 & Impact Assessment and Feedback Statement \\
\hline & S & March 2015 & FRS 104 Interim Financial Reporting \\
\hline \multirow[t]{2}{*}{40} & \multicolumn{3}{|c|}{ FRS 101 (Revised) } \\
\hline & ED & December 2014 & FRED 57 Draft Amendments to FRS 101 Reduced Disclosure Framework \\
\hline \multirow[t]{5}{*}{41} & \multicolumn{3}{|c|}{ Implementation of EU Accounting Directive } \\
\hline & $\mathrm{CO}$ & February 2015 & $\begin{array}{l}\text { Consultation Overview: FREDs 58, } 59 \text { and 60. Implementation of the } \\
\text { EU Accounting Directive }\end{array}$ \\
\hline & DP & February 2015 & $\begin{array}{l}\text { FRED } 58 \text { Draft FRS } 105 \text { The Financial Reporting Standard Applicable to } \\
\text { Micro-entities Regime; FRED } 59 \text { Draft Amendments to FRS 102; FRED } \\
60 \text { Draft Amendments to FRS } 100\end{array}$ \\
\hline & IA & February 2015 & Consultation Stage Impact Assessment \\
\hline & $\mathrm{IA}, \mathrm{FB}$ & July 2015 & $\begin{array}{l}\text { Impact Assessment and Feedback Statement relating to } \\
\text { FRED 50,57,58,59,60 and } 61\end{array}$ \\
\hline
\end{tabular}


Table 3 continued

S July 2015

42

FRS 102 (Revised)

ED April 2015

IA, FB July 2015

S July 2015

43

Client Asset Assurance Standard
ED
May 2015
IA, FB
S

Client Asset Assurance Standard

S November 2015
FRS 105 The Financial Reporting Standard Applicable to Micro-entities Regime; FRS 100 (Revised) Application of Financial Reporting Requirements; FRS 101 (Revised) Reduced Disclosure Framework

FRED 61 Draft Amendments to FRS 102 The Financial Reporting Standard applicable in the UK and Republic of Ireland: Share-based Payment Transactions

Impact Assessment and Feedback Statement relating to FRED 50, 57, 58, 59, 60 and 61

FRS 102 (Revised) The Financial Reporting Standard applicable in the UK and Republic of Ireland

Providing Assurance on Client Assets to the Financial Conduct Authority

Impact Assessment and Feedback Statement

Assurance Standard

$D P$ discussion paper, $I A$ impact assessment (when not presented as part of DP), $E D$ exposure draft, $F B$ feedback paper, $C O$ consultation overview, $S$ standard, $R S$ reporting statement, FRS Financial Reporting Standard, FRSSE Financial Reporting Standards for Smaller Entities, FRED financial reporting exposure draft, UITF Urgent Issues Task Force, ESRA ethical standards for reporting accountants, ISRE International Standard on Review Engagements, SIR standard for investment reporting, ISA (UK and Ireland) International Standard on Auditing adopted in UK and Ireland

\section{References}

Bamber, M., \& McMeeking, K. (2016). An examination of international accounting standard-setting due process and the implications for legitimacy. The British Accounting Review, 48(1), 59-73.

Baskerville, R. F., \& Newby, P. S. (2002). Due process failure in sector-neutral accounting standard-setting. Financial Accountability and Management, 18(1), 1-23.

BIS. (2010). The Financial Reporting Council: A Hampton implementation review report. London: HM Government.

BIS. (2011). Impact assessment guidance: When to do an impact assessment. London: HM Government.

BIS. (2015). Better regulation framework manual: Practice guidance for UK government officials. London: HM Government.

Bovens, M. (2006). Public accountability: A framework for the analysis and assessment of accountability arrangements in the public domain. CONNEX papers, Research Group 2, Democracy and Accountability in the EU.

Bovens, M. (2007). Analyzing and assessing public accountability. A conceptual framework. European Law Journal, 13(4), 447-468.

Cabinet Office. (1998). The regulatory appraisal guide. London: Cabinet Office.

Cabinet Office. (2000). Good policy making: A guide to regulatory impact assessment. London: Cabinet Office.

Cabinet Office. (2003). Better policy making: A guide to regulatory impact assessment. London: Cabinet Office.

Cecot, C., Hahn, R., Renda, A., \& Schrefler, L. (2008). An evaluation of the quality of impact assessment in the European Union with lessons for the US and the EU. Regulation and Governance, 2(4), 405-424.

Coletti, P., \& Radaelli, C. (2013). Economic rationales, learning, and regulatory policy instruments. Public Administration, 91(4), $1056-1070$.

Crawford, L., Ferguson, J., Helliar, C. V., \& Power, D. M. (2014). Control over accounting standards within the European Union:
The political controversy surrounding the adoption of IFRS 8 . Critical Perspectives on Accounting, 25(4-5), 304-318.

Dunlop, C. A., Maggetti, M., Radaelli, C. M., \& Duncan, R. (2012). The many uses of regulatory impact assessment: A metaanalysis of EU and UK cases. Regulation and Governance, 6, 23-45.

Durocher, S., Fortin, A., \& Cote, L. (2007). User's participation in the accounting standard-setting process: A theory building study. Accounting, Organizations and Society, 32(1-2), 29-59.

Fassin, Y. (2009). Inconsistencies in activists' behaviours and the ethics of NGOs. Journal of Business Ethics, 90, 503-521.

Fernandez-i-Marin, X., Jordana, J., \& Bianculli, A. (2015). Varieties of accountability mechanisms in regulatory agencies. In A. Bianculli, X. Fernandez, J. Jordana, \& X. Fernandez-i-Marin (Eds.), Accountability and regulatory governance: Audiences, controls, and responsibilities in the politics of regulation (pp. 23-50). Basingstoke: Palgrave Macmillan.

Financial Reporting Council. (2004). Regulatory strategy, version 1. London: FRC.

Financial Reporting Council. (2009). Regulatory strategy, version 4. London: FRC.

Financial Reporting Council. (2014). The FRC and its regulatory approach. London: FRC.

Fraas, A., \& Lutter, R. (2011). On the economic analysis of regulations at independent regulatory commissions. Discussion Paper. April 2011. RFF, Washington, DC.

Froud, J., Boden, R., Ogus, A., \& Stubbs, P. (1998). Controlling the regulators. London: Macmillan Press.

Froud, J., \& Ogus, A. (1996). 'Rational' social regulation and compliance cost assessment. Public Administration, 74(2), 221-237.

HMSO. (2005). Reducing administrative burdens: Effective inspection and enforcement. London: Her Majesty's Stationary Office.

Hoffmann, S., \& Zulch, H. (2014). Lobbying on accounting standard setting in the parliamentary environment of Germany. Critical Perspectives on Accounting, 25(8), 709-723. 
Humphrey, C., Samsonova, A., \& Siddiqui, J. (2013). Auditing, regulation and the persistence of the expectation gap. In C. van Mourik \& P. Walton (Eds.), The Routledge companion to accounting, reporting and regulation. Abingdon: Routledge.

Jacobs, S. (2005). Improving the quality of regulatory impact assessment in the UK. Centre on Regulation and Competition working paper series. University of Manchester Press, Manchester.

Jacobs, S. (2006). Current trends in process and methods of regulatory impact analysis: The challenges of mainstreaming RIA into policy-making. Washington, DC: Jacobs and Associates Inc.

Jordana, J., Bianculli, A., \& Fernandez-i-Marin, X. (2015). When accountability meets regulation. In A. Bianculli, X. Fernandez, J. Jordana, \& X. Fernandez-i-Marin (Eds.), Accountability and regulatory governance: Audiences, controls, and responsibilities in the politics of regulation (pp. 1-22). Basingstoke: Palgrave Macmillan.

King, D., \& Case, C. (2014). Sarbanes-oxley act and the public company accounting oversight board's first eleven years. Journal of Business and Accounting, 7(1), 11-23.

Kirkpatrick, C., \& Parker, D. (2007). Regulatory Impact assessment: An overview. In C. Kirkpatrick \& D. Parker (Eds.), Regulatory impact assessment: Toward better regulation? (pp. 1-16). Cheltenham: Edward Elgar.

Kwok, W., \& Sharp, D. (2005). Power and international accounting standard setting: Evidence from segment reporting and intangible assets projects. Accounting, Auditing and Accountability Journal, 18(1), 74-99.

Lægreid, P., \& Neby, S. (2016). Gaming. Accountability and trust: DRGs and activity-based funding in Norway, financial accountability and management, 32(1), 0267-4424.

Maggetti, M. (2010). Legitimacy and accountability of independent regulatory agencies: A critical review. Living Reviews in Democracy. http://democracy.livingreview.org

Mandelkern Group on Better Regulation. (2001). Final report. Mandelkern Group on Better Regulation, Brussels.

Mattli, W., \& Buhte, T. (2005). Accountability in accounting? The politics of private rules-making in the public interest. Governance: An International Journal of Policy, Administration and Institutions, 18(3), 399-429.

May, P. (2007). Regulatory regimes and accountability. Regulation \& Governance, 1(1), 8-26.

Meng, X. H., Zeng, S. X., \& Tam, C. M. (2013). From voluntarism to regulation: A study on ownership, economic performance and corporate environmental information disclosure in China. Journal of Business Ethics, 116(1), 217-232.
Mulgan, R. (2003). Holding power to account. Accountability in modern democracies. London: Palgrave.

OECD. (1995). The OECD reference checklist for regulatory decision-making. Paris: OECD.

Osma, B., Gisbert, A., \& Christobal, E. (2014). Public oversight systems for statutory auditors in the European Union. European Journal of Law and Economics, August, 1-36.

Radaelli, C. M. (2004). 'Getting to grips with quality in the diffusion of regulatory impact assessment in Europe', Public Money and Management, October, pp. 271-276.

Radaelli, C. M. (2005). Diffusion without convergence: How political context shapes the adoption of regulatory impact assessment. Journal of European Public Policy, 12(5), 924-943.

Radaelli, C. M. (2010). Regulating rule-making via impact assessment. Governance: An International Journal of Policy, Administration, and Institutions, 23(1), 89-108.

Renda, A. (2006). Impact assessment in the EU: The state of the art or the art of the state. Bruxelles: Centre for European Policy Studies.

Reynolds, M. A., \& Yuthas, K. (2008). Moral discourse and corporate social responsibility reporting. Journal of Business Ethics, 78(1), $47-64$.

Richardson, A. (2008). Due process and standard-setting: An analysis of due process in three Canadian accounting and auditing standard-setting bodies. Journal of Business Ethics, 81, 679-696.

Richardson, A., \& Eberlein, B. (2011). Legitimating transnational standard-setting: The case of the International Accounting Standards Board. Journal of Business Ethics, 98, 217-245.

Righettini, M. S., \& Grimaldi, S. (2015). Social accountability in the regulatory policy process: The governance of telecommunications in Italy. In A. Bianculli, X. Fernandez, J. Jordana, \& X. Fernandez-i-Marin (Eds.), Accountability and regulatory governance: Audiences, controls, and responsibilities in the politics of regulation (pp. 143-165). Basingstoke: Palgrave Macmillan.

Schrefler, L. (2010). The usage of scientific knowledge by independent regulatory agencies. Governance: An International Journal of Policy, Administration, and Institutions, 23(2), 309-330.

Schrefler, L. (2013). Economic knowledge in regulation: The use of expertise by independent agencies. University of Essex: ECPR Press.

Turley, S. (2008). Developments in the framework of auditing regulation in the UK. In R. Quick, S. Turley, \& M. Willekens (Eds.), Auditing trust and governance. London: Routledge.

Vibert, F. (2004). The EU's new system of regulatory impact assessment-a scorecard. London: European Policy Forum.

Yasmin, S., Haniffa, R., \& Hudaib, M. (2014). Communicated accountability by faith-based charity organisations. Journal of Business Ethics, 122, 103-123. 